GOPIT

$I, 9.3$

$1058-F$

.

Geology and Coal Nov 31959

LIBRARY

Resources of the

Homer District

Kenai Coal Field, Alaska

GE L L O I CA L S U R V E Y BUL L E T I N 1058 - F
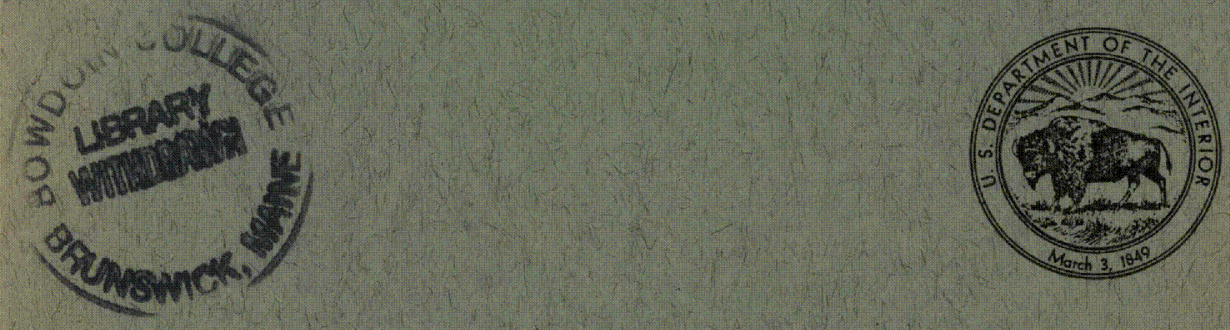



\section{Geology and Coal}

Resources of the

Homer District

Kenai Coal Field, Alaska

By FARRELL F. BARNES and EDWARD H. COBB

M I N RAL RESOURCES OF A LASKA

GEOLOGICAL S URVEY BULLETIN $1058-\mathrm{F}$

A description of the Tertiary stratigraphy and reserves of subbituminous coal of the western Kenai Peninsula, Alaska

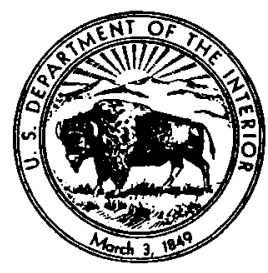




\section{UNITED STATES DEPARTMENT OF THE INTERIOR}

FRED A. SEATON, Secretary

\section{GEOLOGICAL SURVEY}

Thomas B. Nolan, Director

For ale by the Superintendent of Documents, U.S. Government Printing Office Washlngton 25, D.C. 


\section{CONTENTS}

\begin{tabular}{|c|c|}
\hline & Page \\
\hline bstract_. & 217 \\
\hline ion. - - & 217 \\
\hline Purpose and scope of report & 217 \\
\hline Location and extent of district & 218 \\
\hline Fieldwork and acknowledgments & 218 \\
\hline Land surveys. . . & 220 \\
\hline Previous work & 220 \\
\hline eography & 221 \\
\hline Topography & 1 3 \\
\hline Drainage $_{-}$ & 222 \\
\hline$e_{-}$ & 22 \\
\hline$n_{\ldots} \ldots \ldots \ldots$ & 222 \\
\hline settlement $\ldots \ldots \ldots$ & 223 \\
\hline facilities $\ldots \ldots \ldots$ & 223 \\
\hline ( & 224 \\
\hline $\mathbf{n}_{-1-10}$ & 224 \\
\hline nd thickness & 224 \\
\hline (1) & 226 \\
\hline its & 227 \\
\hline 10 & 227 \\
\hline 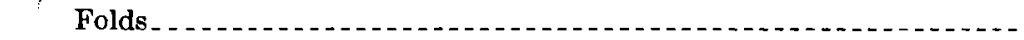 & 227 \\
\hline 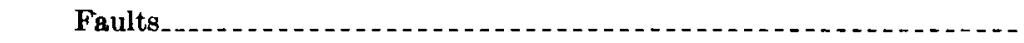 & 228 \\
\hline 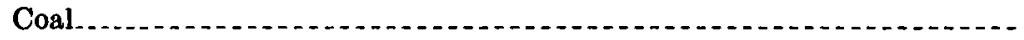 & 229 \\
\hline al beds. & 229 \\
\hline operties.... & 230 \\
\hline - & 230 \\
\hline d development & 231 \\
\hline$x^{2}$ & 234 \\
\hline y townships.................... & 243 \\
\hline $12 \mathrm{~W}_{\ldots} \ldots$ & 243 \\
\hline , R. $12 \mathrm{~W}$ & 243 \\
\hline $13 w \ldots \ldots \ldots$ & 244 \\
\hline $13 W$ & 244 \\
\hline $\mathrm{W}_{\mathrm{W}}$ & 244 \\
\hline (unsurveyed) & 245 \\
\hline 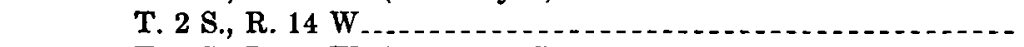 & 245 \\
\hline $10 \mathrm{~W}$. (unsurveyed) & 247 \\
\hline , R. 14 W & 247 \\
\hline $10 \mathrm{~W}$. (unsurveyed) & 247 \\
\hline $11 \mathrm{~W}$. (unsurveyed) & 247 \\
\hline $5 \mathrm{~W}$ & 250 \\
\hline $\mathrm{W}$ & $\mathbf{2 5 0}$ \\
\hline$N_{-12-1}$ & 250 \\
\hline $3 W_{1}$ & \\
\hline , R. $14 \mathrm{~W}_{1}$ & \\
\hline
\end{tabular}




\section{Coal-Continued}

Description of coal by townships-Continued Page

T. 5 S., R. 15 W......... 254

T. 6 S., R. 12 W.

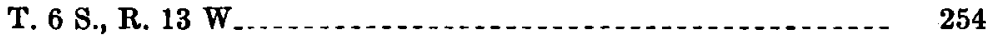

T. 6 S., R. 14 W............................... 256

T. 6 S., R. 15 W.

References cited......... 257

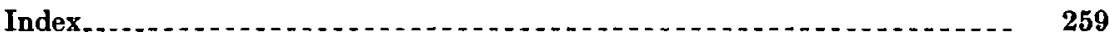

\section{ILLUSTRATIONS}

[All plates in Plate Volume]

Plate 17. Geologic map of the northern part of the Homer district.

18. Geologic map of the southern part of the Homer district.

18. Stratigraphic sections of the Kenai formation.

20. Sections of coal beds at localities 1-33, east shore of Cook Inlet between Capes Kasilof and Ninilchik.

21. Sections of coal beds at localities 34-53, on Deep Creek.

22. Sections of coal beds at localities 54-90, east shore of Cook Inlet between Cape Ninilchik and Bluff Point.

23. Sections of coal beds at localities $91-118$, Tps. 5 and 6 S., R. 14 W.

24. Sections of coal beds at localities 119-135, Tps. 5 and 6 S., Rs. 12 and $13 \mathrm{~W}$.

25. Sections of coal beds at localities 136-157, on the northwest shore of Kachemak Bay between Fritz and Eastland Creeks.

26. Sections of coal beds at localities 158-167, on the northwest shore of Kachemak Bay between Eastland and Swift Creeks.

27. Sections of coal beds at localities 168-177, north of the head of Kachemak Bay.

28. Map and section of the lower Deep Creek area, and graphic logs of power-auger drill holes.

Fradre 43. Index map of south-centeral Alaska, showing areas covered by detailed geologic maps of the Homer district

\section{TABLES}

TABLE 1. Analyses of coal from the Homer district. . .

2. Estimated coal reserves of the Homer district 
MINERAL RESOURCES OF ALASKA

\title{
GEOLOGY AND GOAL RESOURCES OF THE HOMER DISTRICT, KENAI GOAL FIELD, ALASKA
}

\author{
By Farrell F. Barnes and Edward H. Cobb
}

\begin{abstract}
The Homer district of the Kenai coal fleld is about 100 miles southwest of Anchorage, in south-central Alaska. It covers an area of about 1,100 square miles on the west side of the Kenai Peninsula, between Tustumena Lake and Kachemak Bay. The principal settlement is Homer, at the southern end of the district, which is connected by the gravel-surfaced Sterling Highway with the Alaska highway system and The Alaska Railroad, and is also served by ocean transportation and one airline.

About 5,000 feet of nonmarine sedimentary rocks of early Tertiary age is exposed in the district, which is the type area of the coal-bearing Kenai formation. The total thickness of the formation, as well as its relation to older rocks, is unknown, as neither the top nor the base has been found. The bedrock is mostly concealed, except in beach bluffs and along the larger streams, by glacial and alluvial deposits of Quaternary age.

The structure of the district is relatively simple, being characterized by a broad structural basin or trough locally modified by gentle folds and by highangle faults with displacements ranging from a few inches to nearly 80 feet.

The coal of the Homer district ranges in rank from lignite to subbituminous $B$, but the greater part is subbituminous $C$. Coal beds are present throughout the known thickness of the Kenai formation but are thickest and most abundant in the lower part at the south end of the district, where at least 30 beds ranging from 3 to 7 feet in thickness, as well as many thinner beds, were measured. Although mining has been attempted from time to time since 1888 , very little coal has been produced commercially to date.

Indicated reserves, largely within half a mile of the shores of Cook Inlet and Kachemak Bay and in beds containing 2 feet or more of coal, were estimated at about 400 million tons. Much larger reserves are undoubtedly present farther inland, but surface data are insufficient for reliable estimates.
\end{abstract}

\section{INTRODUCTION}

\section{PURPOSE AND SCOPE OF REPORT}

The investigations on which this report is based were made by the United States Geological Survey as part of a program to appraise 
the coal resources of Alaska, determine their geologic features, and assist in the classification of public lands. As the only bedrock exposed in the Homer district is the coal-bearing Kenai formation of Tertiary age, the main objective of the study was the collection of data from which to determine coal reserves and localities favorable for coal mining, as well as the broader aspects of the geology, particularly the nature and structural relations of the rocks that underlie the Kenai formation.

\section{LOCATION AND EXTENT OF DISTRICT}

The Kenai coal field, of which the Homer district is a part, is defined as the coal-bearing part of the Kenai lowland, which lies on the west side of the Kenai Peninsula between the Kenai Mountains and Cook Inlet and extends from Turnagain Arm southward to Kachemak Bay (fig. 43). Although coal-bearing rocks crop out only in the southern part of this area, the entire lowland is probably underlain by the Kenai formation, as suggested by the presence of similar coal-bearing rocks near Anchorage and on the opposite shore of Cook Inlet near Tyonek. The Kenai coal field is therefore considered to be coextensive with the Kenai lowland, but for convenience in description it has been divided into two parts, separated by Tustumena Lake and the Kasilof River. The northern part is designated the Kenai district and the southern part, the Homer district; the names are taken from the principal settlement in each part. The Homer district, which is the subject of this report, includes an area of about 1,100 square miles bounded on the north by Tustumena Lake and the Kasilof River, on the east by the Kenai Mountains and the valley of the Fox River, on the south by Kachemak Bay, and on the west by Cook Inlet (fig. 43).

\section{FIELDWORK AND ACKNOWLEDGMENTS}

This report is based on fieldwork during the summers of 1947 to 1951 and part of the summer of 1954, preceded by a brief reconnaissance in 1946 (Barnes, 1951, p. 203-208). F. F. Barnes was assisted in the field in 1947 by H. C. Wagner, geologist, and L. A. Hale, field assistant; and in 1948 by E. H. Cobb, geologist, and F. J. Markewicz and D. E. Hibbard, field assistants. In 1949 Barnes was assisted by D. M. Ford, geologist, and Cobb was assisted by D. M. Hill, geologist, and F. J. Markewicz, field assistant. In 1950 and 1951 Cobb was assisted by Markewicz, under the general supervision of Barnes. In 1954 Barnes and Daniel Sokol were assisted by A. E. Burford and W. S. Hopkins, geologists, and J. W. Dawson, bulldozer operator-mechanic. 


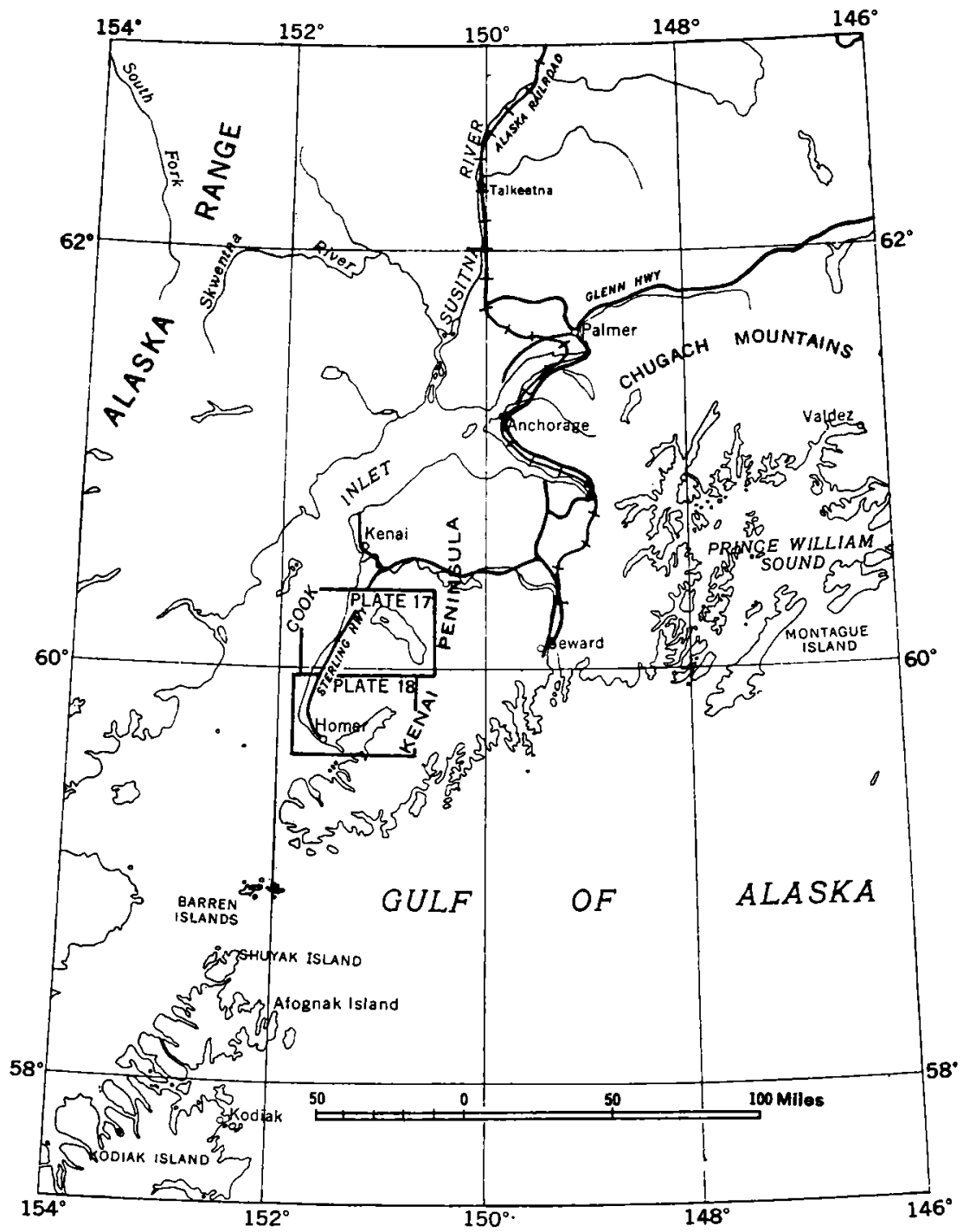

FIG CRE 43.- Index map of south-central Alaska, showing areas covered by detalled geologlc maps (pls. 17 and 18) of the Homer district, Kenal coal field, Alaska.

The fieldwork consisted mostly of measuring and correlating detailed stratigraphic sections of the beach bluffs along the shores of Cook Inlet and Kachemak Bay. These sections, as well as several sections measured along the face of the prominent escarpment north of Homer (pl. 18), herein called the Homer escarpment, were tied to the land-survey net by planetable methods, at a scale of $1: 12,000$. Farther inland the locations of measured sections and isolated outcrops were plotted on aerial photographs at scales of about 1:12,- 
500 and $1: 40,000$. Data from the field maps and aerial photographs were subsequently plotted on topographic quadrangle maps at a scale of $1: 63,360$, all of which became available after completion of the field work. The quadrangle maps were then used as bases for the preparation of the accompanying geologic maps of the Homer district (pls. 17 and 18).

Surface mapping was supplemented in a small area on lower Deep Creek in August 1954 by subsurface exploration with a bulldozer and power-auger unit to test for potential stripping coal.

The writers wish to acknowledge the assistance received during the course of the investigation from many residents of the Homer area. These include the late Evan Jones, former superintendent of the Homer Coal Corp., who provided access to the mine workings and information on mining activities; Bert Hanson, William Lawrence, Ralph Gaetano, and Thomas Shelford, all of Homer, who assisted in reaching isolated coal exposures. J. W. Scott, forester, U.S. Bureau of Land Management, made available the benefits of his knowledge of the Kenai Peninsula. He also accompanied the junior author on several trips to isolated parts of the area. D. B. Krinsley, geologist of the U.S. Geological Survey, furnished information on remote parts of the Homer district that were not visited by the writers.

\section{LAND SURVEYS}

About 400 square miles of the Homer district has been subdivided into townships and sections. The surveyed land consists of a few complete townships in the southwestern part of the district and several fractional or partly surveyed townships covering a narrow belt along the coast between Eastland Creek on Kachemak Bay and the mouth of the Kasilof River. T. 5 S., Rs. 13 and 14 W. and the fractional townships along the coast were surveyed between 1917 and 1920. T. 4 S., Rs. 13 and 14 W.; T. 5 S., R. 12 W.; and the southern third of T. 4 S., R. 12 W. were surveyed in 1940. In the present investigation field mapping was tied to section corners or other points on the land-survey net wherever practicable.

\section{PREVIOUS WORK}

Among the earliest geologic investigations of the Homer district was that made in 1880 by Dall (Dall and Harris, 1892, p. 237-238), who described coal beds on the northwest shore of Kachemak Bay and as far north as Cape Ninilchik (pl. 17). Dall revisited the district in 1895, at which time he examined and sampled coal beds at several prospects and developments on Kachemak Bay (Dall, 1896, p. 788-797). About 1900 Kirsopp (1903, p. 536-559) made a detailed examination of coal deposits of the Homer district. In 1904 a party 
headed by G. C. Martin spent about a month studying the coalbearing rocks of Kachemak Bay (Stone, 1906, p. 53-73), and in 1906 Atwood (1909, p. 121-125) spent a short time in the same general area. In 1911 G. C. Martin revisited the Homer district and later prepared a report incorporating the results of all previous investigations (Martin, 1915, p. 67-97, 104-110).

\section{GEOGRAPHY}

TOPOGRAPHY

Although the part of the Kenai Peninsula west of the Kenai Mountains is referred to as the Kenai lowland, much of the area southwest of Tustumena Lake is a broad, rolling upland, occupying roughly the southeastern half of the Homer district. The upland decreases in altitude southwestward from more than 2,000 feet in the Caribou Fills to less than 1,000 feet at Bluff Point, where it is truncated by the north shore of Kachemak Bay. To the southeast the upland drops off rather abruptly to the Fox River and Kachemak Bay; to the northwest the descent to the coast of Cook Inlet is much more gradual.

The western part of the Homer district, in a belt 8 to 10 miles wide extending from Kachemak Bay northward to the Kasilof River, is relatively flat and poorly drained (pls. 17 and 18), and is characterized by extensive boggy swales in shallow basins and abandoned glacial drainage channels traversed by winding sluggish streams. According to Karlstrom (1955, p. 133), the topography of the Kenai lowland, of which this belt is typical, "exhibits a wide range of glacial and associated fluvioglacial forms such as moraines, outwash aprons and plains, kames, and eskers."

The most significant topographic features of the district in relation to the present study are the prominent wave-cut bluffs that extend almost continuously along the shores of Cook Inlet and Kachemak Bay, for in these bluffs are found the most extensive exposures of the coal-bearing Kenai formation. Along the shore of Cook Inlet north of Anchor Point the bluffs range in height from 50 to 300 feet. Southeastward from Anchor Point they increase gradually in height to a maximum of 800 feet at Bluff Point, east of which they decrease to less than 200 feet near the mine of the Homer Coal Corp., about 1 mile west of Homer, and disappear entirely at the base of Homer Spit. Northeast of the spit, wave-cut bluffs along the northwest shore of Kachemak Bay are less than 50 feet high as far as Fritz Creek, beyond which they again rise gradually to a maximum of 600 feet near the head of the bay. 
Second in importance only to the wave-cut bluffs as sources of bedrock information are the many short but rugged canyons that indent the Homer escarpment or cut the northwest wall of the valley of the Fox River (pl. 18).

\section{DRAINAGE}

The principal streams of the district are the Anchor River and Deep Creek, which carry the drainage of the greater part of the Caribou Hills-Bluff Point upland westward to Cook Inlet. The northern part of the district, including the northeast front of the Caribou Hills, is drained by Nikolai and Crooked Creeks, which flow northwestward to Tustumena Lake and the Kasilof River. The Ninilchik River heads in the lowland south of lower Crooked Creek and flows southwestward parallel to the coast for 15 miles before turning abruptly westward to Cook Inlet. Farther south the lowland belt is drained by Deep and Stariski Creeks and the lower Anchor River. The eastern and southern parts of the district drain into the Fox River and Kachemak Bay through many smaller creeks and canyons, including Fox Creek, which heads in Caribou Lake, Fritz Creek, and Diamond Creek. Many streams of the district, notably Nikolai and Crooked Creeks and the Ninilchik River, flow through valleys that are much too large for the present streams (pl. 17). They were obviously carved by much larger streams, fed by ice tongues that formerly extended into the district from the Kenai Mountains to the east.

\section{CLIMATE}

The Homer district, being somewhat separated from the open ocean, has a climate that is intermediate between that of the coast and that of the interior of Alaska. According to records of the U.S. Weather Bureau (1955), the mean annual temperature is $34.8^{\circ} \mathrm{F}$ at Kasilof and $37.3^{\circ}$ at Homer, and the mean annual precipitation is about 18 inches at Kasilof and 25 inches at Homer. The wettest months are July through September at Kasilof and August through October at Homer. In 1954 the length of the growing season was 104 days at Kasilof and 169 days at Homer. No records are available for the upland areas northeast of Homer. According to local residents, the growing season on the 1,000-foot upland north of the Homer escarpment is generally at least 2 weeks shorter than on the lower bench on which the town is situated.

\section{VEGETATION}

The vegetation of the Kenai lowland consists of intermixed forest, muskeg, grassland, and subalpine shrub tundra (Karlstrom, 1955, p. 133). The forests include stands of white and Sitka spruce and 
mixed stands of spruce, birch, aspen, and balsam poplar. The mixed forests of spruce and birch and of spruce and aspen are limited to the better drained areas where seasonally frozen ground thaws relatively early. Pure stands of stunted white or black spruce grow in areas of more restricted drainage and lingering seasonal frost.

Muskeg vegetation, including mosses, grasses, sedges, heath shrubs, and scattered black spruce, is found in broad, shallow drainage basins and abandoned glacial channels, where subsurface drainage is poor and frost persists at a shallow depth during most of the summer, Grassland vegetation, in which bluejoint and other grasses, wild celery (Heracleum lanatum), and fireweed predominate, grows chiefly on slopes and broad upland summits, and also in the better drained abandoned glacial drainage channels. Intermixed with the forest and grassland types of vegetation are a variety of shrubs, including high-bush cranberry, wild rose, devilsclub, and the larger red elderberry and alder, which generally form dense thickets.

\section{LAND USE AND SETTLEMENT}

Much of the land in the general vicinity of Homer and along the Sterling Highway has been taken up by homesteaders engaged in varying degrees in farming, dairying, and stock and poultry raising. The principal crops, most of which are consumed locally, are hay, potatoes, root crops, and berries. Many homesteaders supplement their income in other occupations, particularly commercial fishing, which is the principal industry of the Homer district.

The principal settlements of the district are Homer, Anchor Point, and Ninilchik, in addition to which several smaller communities are scattered along the coast north of Anchor Point. Homer is by far the largest settlement. It contains several stores, garages, restaurants, and other business establishments and is the main supply center of the district.

\section{TRANSPORTATION FACILITIES}

The Homer district is connected with the Alaskan highway system by the Sterling Highway, a gravel-surfaced road that extends from Homer along the coast to and beyond the northern boundary of the district and then eastward to connect with the Anchorage-Seward highway and The Alaska Railroad. Branch roads connect the Sterling Highway with Cohoe and Kasilof, near the mouth of the Kasilof River, and with Kenai, several miles north of the district. A large area north and east of Homer is made accessible by a network of secondary roads. A 41/2-mile road connects Homer with the dock and other facilities at the tip of Homer Spit.

Water transportation is provided by ocean-going freighters and tankers, as well as by smaller boats that ply Cook Inlet. An airline 
provides daily service between Homer and Anchorage and less frequent service to other points in Alaska. The 5,000-foot gravel-surfaced Homer airfield, maintained by the Civil Aeronautics Administration, will accommodate all but the largest aircraft. Smaller landing strips for light planes are maintained at Anchor Point, Ninilchik, and Kasilof. Excellent floatplane landing and anchorage facilities are provided by a 2-mile-long artificial lake near the Homer airport.

\section{STRATIGRAPHY}

The only known bedrock within the Homer district is the Kenai formation of Tertiary age, which probably underlies the Kenai lowland beneath an almost continuous cover of glacial and alluvial deposits. The nearest exposed older rocks are those of the Kenai Mountains to the east, which include slate, graywacke, chert, ellipsoidal lava, and greenstone that are probably at least in part of Cretaceous age (Capps, 1940, p. 54-55).

\section{KENAI FORMATION}

The Kenai formation, whose type locality is in the Homer district, is considered to be of fresh-water origin and to belong to the upper part of the Eocene series (Smith, 1939, p. 61). Although the formation probably was deposited very close to sea level, no stratigraphic or fossil evidence has been found to indicate that any of the beds were formed under marine conditions; instead, the nature of the beds and the presence of plant fossils indicate that they were formed on land.

\section{ChaRACTER AND THICKNEgS}

The Kenai formation consists of moderately indurated sand, silt, and clay in generally thin and intergrading beds and lenses, interbedded with a few thin lenses of fine conglomerate and many beds of subbituminous and lignitic coal ranging from a few inches to 7 feet in thickness. Thin layers of volcanic ash were found as partings in several coal beds near the head of Kachemak Bay (pls. 26 and 27). Ferruginous masses in thick sandstone beds, and ironstone concretions, in distinct bands and as scattered nodules, are common throughout the formation except to the north of Ninilchik, where they are relatively scarce. The resistant masses of sandstone are particularly noticeable on some sections of beach where they have accumulated as irregular-shaped boulders as the wave-cut bluffs receded.

Stratigraphic sections measured in different parts of the Homer district (pl. 19) are strikingly similar, with a few exceptions. In the extreme northwestern part of the district the beds are characterized by a decrease in the degree of induration and in the quality and rank of the coal, and by a marked increase in the proportion of sand- 
stone. The rocks consist of poorly indurated silt and clay, and the coal is dull brown and lignitic, in contrast to the black shiny coal generally found in other parts of the district. Another possibly significant change in the character of the Kenai formation was noted along the eastern border of the district, where the color of the strata exposed in the canyon of Fox Creek changes abruptly from typical light buff in the lower part of the canyon walls to light bluish gray in the upper part. The change apparently occurs at a bedding plane. Although the contact between buff and bluish gray beds was not found in the west side of the valley of the Fox River, it is known to lie south of locality 177 ( $\mathrm{pl} .18$ ), as all beds exposed from that locality northward are bluish gray.

Probably the most important change noted in the measured sections of the Kenai formation is a decrease northward in the number and thickness of coal beds. This change was noted along both margins of the district, as illustrated by sections north of Clam Gulch and at locality 177 (pl. 19), and especially by the almost total absence of coal in the extensive exposures north of both sections.

The total thickness of the Kenai formation is not known, as neither the top nor the base has been recognized, but it probably exceeds 4,700 feet. This figure is the aggregate thickness of sections measured along the northwest shore of Kachemak Bay, which were correlated by means of traceable beds or by projection along probable bedding planes where identifiable beds could not be traced between sections. The stratigraphically lowest beds included are exposed along the beach south of Anchor Point and the highest, at the head of Swift Creek (pl. 18). None of the sections measured northeast of Swift Creek could be definitely correlated with the Kachemak Bay sections or with each other because of discontinuity of outcrops and lack of recognizable key beds, and also because the variable dip of the beds made projection of bedding planes for more than short distances highly untrustworthy. However, a general northwest dip indicates that several hundred feet of bluish-gray beds exposed in upper Fox Creek canyon and in the bluffs northeast of locality 177 overlie those at the head of Swift Creek, thus raising the probable thickness of the Kenai formation to 5,000 feet or more.

About 2,000 feet of strata are exposed along the beach between Ninilchik and Cape Starichkof, and several other sections, including 2 of about 1,000 feet, were measured farther north (pl, 19). The stratigraphic relations of these sections to each other and to the Kachemak Bay section to the south are in doubt because of the lack of key beds for correlation across concealed intervals and across faults of unknown displacement. Available information indicates that in general, except for a few local reversals resulting from minor 
folding, progressively younger beds are exposed northward from Cape Starichkof, and that these sections are in large part, if not entirely, duplicated by the Kachemak Bay section.

\section{DISTRIBUTION}

Beds of the Kenai formation are exposed intermittently in the beach bluffs along the coast between Kasilof and Homer, and almost continuously along the northwest shore of Kachemak Bay from Fritz Creek to the head of the bay (pls. 17 and 18). They appear in many bluffs and canyon walls on the west side of the valley of the Fox River, to a point about 11 miles above the head of the bay, opposite which Kenai strata also underlie a small area on the east side of the Fox River (pl. 18). At no point is the contact with the older rocks of the adjacent Kenai Mountains exposed, but the fact that the Kenai strata east of the river dip northeastward into the mountain face suggests a fault relation in which the older rocks to the east were upthrown.

A single small outcrop of rocks that presumably belongs to the Kenai formation was mapped at the head of Crystal Creek, a southeast tributary of Tustumena Lake (pl. 17), where a section comprising 35 feet of conglomerate, sandstone, siltstone, and claystone was measured. These beds are poorly indurated and contain carbonized wood fragments, in both respects resembling beds in the Kenai formation in the northwestern part of the district. The beds on Crystal Creek have a relatively steep dip of about $25^{\circ} \mathrm{SW}$., but as their contact with the older rocks of the Kenai Mountains is concealed by glacial deposits their structural relations to them could not be determined.

The southwest shore of Tustumena Lake was not examined in detail, but a few ground observations, aerial reconnaissance, and oral reports of geologists of the Alaska Terrain and Permafrost Section of the U. S. Geological Survey indicate that only glacial and alluvial deposits are exposed.

Isolated outcrops of the Kenai formation were mapped in the valleys of the Ninilchik and Anchor Rivers (pls. 17 and 18), in several smaller valleys on the upland between Homer and the Anchor River, and on the south slope of Ptarmigan Head in the Caribou Hills (pl. 17). Kenai bedrock was traced almost continuously along the middle course of Deep Creek and observed in several scattered outcrops along its lower course (pl. 17).

Combined aerial and ground reconnaissance, supplemented by photogeologic interpretation, of extensive areas between Homer and the Anchor River, northwest of the Anchor River, and on the south face of Bald Mountain (pl. 18) indicated that they are underlain by the Kenai formation beneath a comparatively thin mantle of surficial deposits; these areas are therefore shown as Kenai on the geo- 
logic maps. The presence of a large area of Kenai rocks at the heads of Crooked and Nikolai Creeks on the northeast face of the Caribou Hills (pl. 18) was reported by D. B. Krinsley (oral communication, October 1951). The small area of Kenai rocks on a tributary of Deep Creek (pl. 17) northwest of Ninilchik Dome (pl. 18) was mapped by aerial reconnaissance and photogeologic interpretation.

\section{SURFICIAI DEPOSITS}

Most of the Homer district is mantled with glacial deposits and alluvial silt, sand, and gravel to depths ranging from a few inches to several tens of feet. Locally, in what appear to be buried stream channels exposed in the beach bluffs, the thickness of unconsolidated deposits may be several hundred feet. Other types of surficial deposits include loess, or wind-deposited silt, which covers the HomerAnchor Point area to depths of as much as 2 feet (Krinsley, 1953, p. 6) ; landslide debris at the foot of beach bluffs, notably southeast of Bluff Point; and colluvium on many gentle upland slopes. Thin layers of volcanic ash, appearing as light-colored streaks in fresh exposures of alluvium, loess, and peat, were noted at several places.

Beach sands along the east shore of Cook Inlet, notably at Anchor Point, have yielded small amounts of placer gold, apparently concentrated by wave action from glacial and alluvial gravels (Martin, 1915 , p. 110-111).

\section{STRUCTURE}

The structure of the Kenai formation in the Homer district is relatively simple, being characterized by broad, gentle folds in which the dips are generally less than $10^{\circ}$, and by high-angle faults with vertical displacements ranging from a few inches to nearly 80 feet. Little is known of the trend and extent of the fold axes and faults, most of which are evident only in the nearly vertical beach bluffs. The general trend of the fold axes appears to be to the northeast, and the faults, with a few exceptions, strike northwestward. These structures are superposed on a broader structural basin or trough whose rim generally parallels the shores of Cook Inlet and Kachemak Bay.

\section{FOLDS}

A series of broad, gentle folds, including 4 anticlines and 3 synclines, is revealed by reversals of the apparent dip of beds exposed in the beach bluffs between Deep Creek and Clam Gulch (see section on plate 17). Th only indication of the trend of these folds was found at localities 23 and 25 (pl. 17), where 2 small folds are well enough exposed in 3 dimensions to show a trend of about N. $65^{\circ} \mathrm{E}$. No folds are apparent in the almost continuous bedrock exposures in the beach 
bluffs between Deep and Happy Creeks, but several miles inland beds exposed along Deep Creek east of locality 37 have undergone the strongest folding noted anywhere in the Homer district, with local dips of nearly $20^{\circ}$ (pl. 17). The plotted dips outline a broad anticline between localities 37 and 45 , a very narrow syncline between localities 50 and 51 , and an equally narrow anticline between localities 51 and 52 . The limbs of these narrow folds are nearly parallel and indicate an axial trend slightly east of north. About 3 miles farther upstream, two converging dips of about $5^{\circ}$ possibly reflect a gently northeastward plunging syncline.

Between Anchor Point and Homer the beds exposed in the beach bluffs have been gently folded into at least 6 synclines and 5 anticlines, several of which are shown in section on plate 18. Indications of axial trends are mostly lacking here also but evidence indicates that these folds likewise plunge gently northeastward.

On the northwest shore of Kachemak Bay northeast of Homer (pl. 18), exposures in the beach bluffs reveal an anticlinal axis east of the mouth of Fritz Creek, and both an anticline and a syncline west of the mouth of Cottonwood Creek (see section on plate 18). No evidence was found to show the trend of these folds.

\section{FAULTS}

The beds of the Kenai formation are cut by 35 faults or more, all but one of which are normal faults with steep to vertical dips. More than 20 faults, with vertical displacements of 3 to 77 feet and dips ranging from $50^{\circ}$ to vertical, were mapped in the beach bluffs along the shore of Kachemak Bay between Fritz and Swift Creeks (pl. 18). Although the strikes of these faults could not be determined accurately in the nearly vertical exposures, they appear to range from due north to due west, the general trend being northwest. The direction of displacement was not the same at all these faults, but the predominating movement was upthrow of the northeast block, with the net result that beds at the head of the bay have been upthrown nearly 250 feet relative to those at the mouth of Fritz Creek. Farther west, northwestward-trending faults were mapped at localities 124 and 127, on the Homer escarpment, and at locality 132, on the beach south of Millers Landing. At these 3 faults the northeast side was upthrown about 50,40 , and 10 feet, respectively.

Comparatively few faults were mapped in the western part of the Homer district, possibly owing in part to poorer and less extensive exposures of bedrock. Complex faulting near locality 76 (pl. 18) has disturbed beds at the crest of a small anticline south of Troublesome Creek; there the aggregate effect of 3 faults has been to drop the southeast side about 23 feet stratigraphically. These 3 faults, with 
strikes ranging from N. $12^{\circ} \mathrm{E}$. to N. $80^{\circ} \mathrm{E}$., are the only northeastwardtrending faults, with the exception of a small reverse fault north of Ninilchik, that were observed in the Homer district.

Three small faults near the mouth of Happy Creek (pl. 17) strike due west to N. $30^{\circ} \mathrm{W}$., and have vertical displacements of 6 to 8 feet.

The only reverse fault seen in the district is exposed in the beach cliff near locality $27,11 / 2$ miles north of Ninilchik (pl. 17). Although the fault surface could not be reached for direct measurement, it was estimated to have a strike of N. $45^{\circ} \mathrm{E}$., and a dip of $58^{\circ} \mathrm{SE}$., and a vertical displacement of 20 feet.

Two normal faults with northwest strikes and steep northeast dips are exposed in the beach bluffs north of Corea Creek and north of Falls Creek (pl. 17). As no correlation of beds could be made across either of these faults, the amount of displacement is unknown, but drag of coal beds along the faults indicates that in each case the southwest side was upthrown. The faults mapped at the mouth of Clam Gulch and about a mile to the south are not exposed, but were inferred to account for discrepancies in stratigraphic sections on opposite sides of concealed intervals. Several small faults with displacements of less than 5 feet were observed, but not mapped, between Deep Creek and Clam Gulch.

COAL

\section{CHARACTER AND DISTRIBUTION OF COAL BEDS}

The coal of the Homer district occurs in many lenticular beds, including at least 30 beds ranging from 3 to 7 feet in thickness, that are widely distributed throughout the known thickness of the Kenai formation. In the southern part of the district, the coal beds are thickest and most abundant in the lower part of the exposed section. Individual beds generally change markedly in both thickness and purity within short distances, which makes correlation difficult or impossible except where beds can be traced almost continuously between sections. One notable exception is the Cooper coal bed, which remains fairly uniform where exposed in the beach bluff for about a mile westward from the Homer Coal Corp. mine (pl. 18), and changes gradually to a thinner multiple bed about 3 miles farther west at Bluff Point (pl. 23, sections 107-118). More typical of the coal beds of the districts are beds $E$ and $F$, which are exposed almost continuously for several miles along the shore of Kachemak Bay northeast of McNeil Creek. Changes in thickness and number of partings in these beds are illustrated by detailed sections at localities 144-157 (pl. 25).

The general distribution of coal beds throughout the known thickness of the Kenai formation is shown by the stratigraphic sections (pl. 19), and detailed sections of the principal coal beds of the district $489861-59-3$ 
are shown on plates 20-27. Inasmuch as individual coal beds are exposed only in a narrow zone along the beach bluffs or in isolated exposures at inland points, little is known of their areal extent. It is reasonable to assume that they extend back from their outcrops for at least a distance commensurate with their outcrop lengths, and that these or related beds underlie the greater part of the Homer district.

\section{PHYSICAL AND CHEMICAL PROPERTIES}

The coal of the Homer district is generally a dull black, with many bright, lustrous bands in fresh exposures, and has a dark-brown streak. Locally it has one prominent cleat, or fracture, and a poorer one, which are at right angles to each other and to the bedding. The strike of the prominent cleat is remarkably uniform throughout the district; all measurements are between N. $40^{\circ} \mathrm{W}$. and N. $60^{\circ} \mathrm{W}$. Some of the beds are composed in large part of flattened coalified tree trunks and limbs, some of which retain the original grain structure and split like wood. In weathered exposures the coal is dark gray and its woody texture is emphasized, resulting in a rough platy fracture parallel to the bedding.

The analyses in table 1 show that most of the coal of the Homer district is subbituminous $C$ in rank although 3 of the 18 samples are classed as lignite and at least 2 as subbituminous $B$ coal. The average heating value of the samples analyzed is about 7,700 Btu as received, or $8,900 \mathrm{Btu}$ air-dried. The ash content ranges from 3.2 to 22.6 percent as received, or 4.0 to 24.5 percent air-dried.

\section{BURNING OF COAT BEDS}

Burned coal beds are found in many parts of the Homer district, particularly near the head of Kachemak Bay. These beds are indicated by thick zones of yellow to brick-red shaly rock that is generally highly shattered and baked to a flinty hardness. The coal beds are generally represented by 1 to 2 inches of soft yellow ash at or near the base of the baked zone.

A few small burned zones are found along the Homer escarpment, and several extensive burned zones are exposed in the beach bluffs in the vicinity of Cottonwood Creek. In several long sections of bluff between Eastland and Swift Creeks practically all the coal beds have been burned. The only outcrops of unburned coal are in the bottoms of ravines where the coal is kept wet by springs. The only burned beds seen in the western and northwestern parts of the district are on Deep Creek below locality 35, and in the beach bluff at locality 28, about a mile north of Ninilchik.

Much of the burning is believed to have occurred in comparatively recent years. According to local reports many of the beds along the 
northwest shore of Kachemak Bay were burning within the memory of older residents. This agrees with the fact that Stone, who examined the coal of Kachemak Bay in 1904, mentioned burned beds only in the upper part of the bluffs between Falls Creek and the head of the bay (Stone, 1906, p. 66). On the other hand, beds of ash and baked shale were found at a few places beneath several feet of soil, indicating that some burning occurred much earlier. Little evidence was found to indicate how far back from the outcrop the coal had burned, but it is doubtful that it would continue to burn under more than a few tens of feet of cover.

\section{HISTORY OF MINING AND DEVELOPMENT}

Coal-mining activities in the Homer district before 1904 have been summarized by R. W. Stone (1906, p. 54-56). Probably the first coal mining in the district was begun in 1888 when the Alaska Coal Co., drove a tunnel on a coal seam about a mile south of Millers Landing (loc. 132). Nothing is known of the production from this bed, which was known as the Bradley seam. No trace of the tunnel remains.

In 1891 Lt. R. P. Schwerin, U.S. Navy, took 50-ton samples from each of the 4 localities on Kachemak Bay, one of which was McNeil Canyon (loc. 144), and shipped them to San Francisco for testing. The results did not encourage further development.

In 1894 the North Pacific Mining and Transportation Co. began exploration in Eastland Canyon (loc. 158). The company erected three buildings and a short pier at the mouth of the canyon and built a tramway to a tunnel on a coal seam half a mile up the canyon. At least 650 tons of coal was mined and shipped to San Francisco for testing.

Prospecting in Eastland and McNeil Canyons was continued from 1894 to 1897 by the Alaska Coal Co. and the North Pacific Mining and Transportation Co. During this time two short tunnels were driven on the Curtis seam (bed $B$, loc. 143) a short distance west of McNeil Canyon, and a short wharf and coal bunkers were built.

Extensive preparations for coal development in the Homer district were made from 1899 to 1902 by the Cook Inlet Coal Fields Co. in the vicinity of Bidarki Creek. This company built a large dock at the tip of Homer Spit and a 42-inch-gage railroad from the dock to Bidarki Creek. Underground work included the driving of 3 tunnels on the Cooper coal bed in the beach bluff and the starting of 2 shafts a short distance back from the bluff. Despite the rather extensive development work, the total production by this company was apparently only a few hundred tons.

According to available records, the next coal-mining activity in the Homer district was in 1915, when operations were resumed at the 
TABLE 1.-Analyses of coal from Homer district, Kenai coal field, Alaska

[Condition of sample: A, as received; B, air-dried; C. moisture-free; D, molsture- and ash-free]

\begin{tabular}{|c|c|c|c|c|c|c|c|c|c|c|c|c|c|}
\hline $\begin{array}{c}\text { Reference } \\
\text { letter on } \\
\text { geologic } \\
\text { maps }\end{array}$ & Location of sample & $\begin{array}{c}\text { Collector and } \\
\text { date }\end{array}$ & $\begin{array}{c}\text { Rank } 1 \text { and calcu- } \\
\text { lated moist } \\
\text { mineral-free } \\
\text { heating value } \\
\text { (Btu) }\end{array}$ & $\begin{array}{c}\text { D.S. } \\
\text { Bureau of } \\
\text { Mines } \\
\text { Labcratory } \\
\text { No. }\end{array}$ & $\begin{array}{c}\text { Loss on } \\
\text { air } \\
\text { drying }\end{array}$ & $\begin{array}{c}\text { Con- } \\
\text { dition } \\
\text { of } \\
\text { sample }\end{array}$ & $\begin{array}{c}\text { Mois- } \\
\text { ture }\end{array}$ & $\begin{array}{l}\text { Volatile } \\
\text { matter }\end{array}$ & $\begin{array}{c}\text { Fixed } \\
\text { carbon }\end{array}$ & $\Delta s h$ & Sulfur & $\begin{array}{l}\text { Heating } \\
\text { value } \\
\text { (Btu) }\end{array}$ & $\begin{array}{l}\text { Thick- } \\
\text { ness in } \\
\text { sample } \\
\text { (feet) }\end{array}$ \\
\hline $\mathbf{A}$ & $\begin{array}{l}\text { Loc. } 7 \text {, sec. } 6, \text { T. } 1 \text { N., R. } 12 \text { W.; } \\
\text { outcrop in beach bluff. }\end{array}$ & E. H. Cobb, & Lignite $(8,000) \ldots$ & D-51010 & 17.2 & $\begin{array}{l}\mathbf{A} \\
\mathbf{B} \\
\mathbf{C} \\
\mathbf{D}\end{array}$ & \begin{tabular}{r}
27.1 \\
12.0 \\
\hdashline-2. \\
\end{tabular} & $\begin{array}{l}31.8 \\
38.4 \\
43.7 \\
55.7\end{array}$ & $\begin{array}{l}25.4 \\
30.6 \\
34.7 \\
44.3\end{array}$ & $\begin{array}{l}15.7 \\
19.0 \\
21.6\end{array}$ & $\begin{array}{r}0.2 \\
.2 \\
.3 \\
.3\end{array}$ & $\begin{array}{r}6,640 \\
8,020 \\
9,110 \\
11,620\end{array}$ & 3.6 \\
\hline $\mathbf{B}$ & $\begin{array}{l}\text { Loc. } 28 \text {, sec. } 26, \text { T. } 1 \text { S., R. } 14 \text { W.; } \\
\text { outcrop in beach bluif. }\end{array}$ & -....do do & $\begin{array}{l}\text { Subbituminous } \\
\mathbf{C}(8,460)\end{array}$ & $D-49805$ & 14.5 & $\begin{array}{l}\mathbf{A} \\
\mathbf{B} \\
\mathbf{C} \\
\mathbf{D}\end{array}$ & $\begin{array}{r}27.1 \\
14.8 \\
\hdashline . . . \\
\hdashline-. .9\end{array}$ & $\begin{array}{l}36.5 \\
42.7 \\
50.1 \\
56.3\end{array}$ & $\begin{array}{l}28.4 \\
33.1 \\
38.9 \\
43.7\end{array}$ & $\begin{array}{r}8.0 \\
9.4 \\
11.0 \\
\end{array}$ & $\begin{array}{l}.3 \\
.3 \\
.4 \\
.4\end{array}$ & $\begin{array}{r}7.730 \\
9,040 \\
10,610 \\
11,920\end{array}$ & 2.5 \\
\hline C & $\begin{array}{l}\text { Loc. 35, sec. } 3 \text {, T. } 2 \text { S., R. } 14 \text { W.; } \\
\text { outcrop in bank of Deep Cr. }\end{array}$ & $\begin{array}{l}\text { F. F. Barnes, } \\
1954\end{array}$ & Lignito $(7,850)$ & $A-2$ & & A & 30.4 & $\begin{array}{l}41.3 \\
58.3\end{array}$ & $\begin{array}{l}24.5 \\
35.2\end{array}$ & $\begin{array}{l}3.8 \\
5.5\end{array}$ & .2 & $\begin{array}{r}7,636 \\
10,828\end{array}$ & 4.3 \\
\hline $\mathrm{D}$ & $\begin{array}{l}\text { Loc. } 57 \text {, sec. } 29, \text { T. } 2 \mathrm{~S} \text {., R. } 14 \text { W.; } \\
\text { outcrop in beach bluff. }\end{array}$ & $\begin{array}{l}\text { E. H. Cobb, } \\
1850 .\end{array}$ & $\begin{array}{l}\text { Subbituminous } \\
\mathbf{C}(8,350)\end{array}$ & D-51009 & 13.8 & $\begin{array}{l}\mathbf{A} \\
\stackrel{\mathbf{B}}{\mathbf{C}} \\
\mathbf{D}\end{array}$ & \begin{tabular}{r}
26.0 \\
14.1 \\
\hdashline-1 \\
-
\end{tabular} & $\begin{array}{l}34.2 \\
39.7 \\
46.2 \\
55.1\end{array}$ & $\begin{array}{l}27.8 \\
32.3 \\
37.6 \\
44.8\end{array}$ & $\begin{array}{l}12.0 \\
13.9 \\
16.2 \\
-. .\end{array}$ & $\begin{array}{l}.2 \\
.2 \\
.2 \\
.3\end{array}$ & $\begin{array}{r}7,260 \\
8,420 \\
9,800 \\
11,700\end{array}$ & 6.1 \\
\hline $\mathbf{E}$ & $\begin{array}{l}\text { Loc. } 59 \text {, sec. } 29, \text { T. } 2 \text { S., R. } 14 \text { W.; } \\
\text { outcrop in beach bluff. }\end{array}$ & $\ldots$ do & $\begin{array}{l}\text { Subbituminous } \\
\mathrm{C}(\mathbf{8}, \mathbf{4 5 0 )} \text {. }\end{array}$ & D-49804 & 14.2 & $\begin{array}{l}\mathbf{A} \\
\mathbf{B} \\
\mathbf{D} \\
\mathbf{D}\end{array}$ & $\begin{array}{r}27.0 \\
14.9 \\
\hdashline-1\end{array}$ & $\begin{array}{l}34.5 \\
40.2 \\
47.3 \\
54.5\end{array}$ & $\begin{array}{l}28.8 \\
33.6 \\
39.4 \\
45.5\end{array}$ & $\begin{array}{r}9.7 \\
11.3 \\
13.3 \\
-. .\end{array}$ & $\begin{array}{r}.2 \\
: 2 \\
: 3 \\
.3\end{array}$ & $\begin{array}{r}7,690 \\
8,850 \\
10.390 \\
11,980\end{array}$ & 41 \\
\hline $\mathbf{F}$ & $\begin{array}{l}\text { Loc. } 64 \text {, sec. } 32, \text { T. } 2 \text { S., R. } 14 \text { W.; } \\
\text { outcrop in beach bluff. }\end{array}$ & -...do do & $\begin{array}{l}\text { Subbituminous } \\
\mathbf{C}(8,500)\end{array}$ & D-48015 & 11.3 & $\begin{array}{l}\mathbf{A} \\
\mathbf{B} \\
\mathbf{C} \\
\mathbf{D}\end{array}$ & $\begin{array}{r}27.0 \\
17.7 \\
\hdashline\end{array}$ & $\begin{array}{l}35.3 \\
39.8 \\
48.3 \\
54.0\end{array}$ & $\begin{array}{l}30.0 \\
33.8 \\
41.2 \\
46.0\end{array}$ & $\begin{array}{r}7.7 \\
8.7 \\
10.5\end{array}$ & $\begin{array}{l}.2 \\
.2 \\
.2 \\
.3\end{array}$ & $\begin{array}{r}7,800 \\
8,800 \\
10,690 \\
11,950\end{array}$ & $\mathbf{3 . 3}$ \\
\hline$G$ & $\begin{array}{l}\text { Loc. } 67 \text {, sec. } 7, \mathrm{~T} .3 \mathrm{~S} ., \mathrm{R} .14 \mathrm{~W} . \\
\text { outcrop } 30 \text { feet south of mouth of } \\
\text { Happy Creek. }\end{array}$ & $\begin{array}{l}\text { E. H. Cobb, } \\
\text { 1950. }\end{array}$ & $\begin{array}{l}\text { Subbituminous } \\
\mathrm{C}(8,660)\end{array}$ & D-48110 & 7.7 & $\begin{array}{l}\mathbf{A} \\
\mathbf{B} \\
\mathbf{C} \\
\mathbf{D}\end{array}$ & $\begin{array}{r}22.1 \\
15.6\end{array}$ & $\begin{array}{l}31.2 \\
33.8 \\
40.1 \\
56.4\end{array}$ & $\begin{array}{l}24.1 \\
26.1 \\
30.9 \\
43.0\end{array}$ & $\begin{array}{l}22.0 \\
24.5 \\
29.0\end{array}$ & $\begin{array}{l}.2 \\
.2 \\
.3 \\
.4\end{array}$ & $\begin{array}{r}6,550 \\
7,100 \\
8,410 \\
11,850\end{array}$ & 3.8 \\
\hline $\mathrm{H}$ & $\begin{array}{l}\text { Loc. } 77 \text {, sec. } 27, \text { T. } 5 \mathrm{~S} \text {., R. } 15 \mathrm{~W} . ; \\
\text { outcrop in beach bluff. }\end{array}$ & (.....do. do & $\begin{array}{l}\text { Subbituminous } \\
\mathrm{B}(9,550)\end{array}$ & D-48905 & 8.6 & $\begin{array}{l}\mathbf{A} \\
\mathbf{B} \\
\mathbf{C} \\
\mathbf{D}\end{array}$ & $\begin{array}{r}21.2 \\
13.9\end{array}$ & $\begin{array}{l}35.6 \\
38.9 \\
45.1 \\
56.1\end{array}$ & $\begin{array}{l}27.8 \\
30.4 \\
35.4 \\
43.9\end{array}$ & \begin{tabular}{c}
15.4 \\
16.8 \\
19.5 \\
\hdashline$\ldots .$.
\end{tabular} & $\begin{array}{l}.3 \\
.3 \\
.4 \\
.5\end{array}$ & $\begin{array}{r}7,920 \\
8,650 \\
10,050 \\
12,480\end{array}$ & 3.4 \\
\hline I & $\begin{array}{l}\text { Loc. } 106 \text {, sec. } 12, \text { T. } 6 \text { S., R. } 14 \text { W.; } \\
\text { small strip pit on Kranich farm. }\end{array}$ & $\begin{array}{l}\text { F. F. Barnes, } \\
1947 \text {. }\end{array}$ & $\begin{array}{l}\text { Subbltuminous } \\
\mathrm{C}(8,550)\end{array}$ & C-83515 & 18.4 & $\begin{array}{l}\mathbf{A} \\
\mathbf{B} \\
\mathbf{C} \\
\mathbf{D}\end{array}$ & \begin{tabular}{r}
27.7 \\
11.4 \\
\hdashline \\
\end{tabular} & $\begin{array}{l}38.1 \\
46.7 \\
52.7 \\
55.2\end{array}$ & $\begin{array}{l}31.0 \\
37.9 \\
42.8 \\
44.8\end{array}$ & $\begin{array}{l}3.2 \\
4.0 \\
4.5\end{array}$ & $\begin{array}{l}.1 \\
.2 \\
.2 \\
.2\end{array}$ & $\begin{array}{r}8,220 \\
10,080 \\
11,370 \\
11,900\end{array}$ & 2.7 \\
\hline
\end{tabular}




\begin{tabular}{|c|c|c|c|c|c|c|c|c|c|c|c|c|}
\hline $\mathbf{J}$ & $\begin{array}{l}\text { Loc. 116, sec. 24, T. } 6 \text { S, R. } 14 \mathrm{~W} \text {. } \\
\text { uppermost coal exposed in beach } \\
\text { cliff (Bed 5). }\end{array}$ & $\begin{array}{l}\text { T. R. Jolley, } \\
\text { 1946. }\end{array}$ & $\begin{array}{l}\text { Subbituminous } \\
\text { B-C }(9,500) \text {. }\end{array}$ & C-61954 & 12.9 & $\begin{array}{l}\mathbf{A} \\
\mathbf{B} \\
\mathbf{C} \\
\mathbf{D}\end{array}$ & $\left|\begin{array}{r}22.7 \\
11.2 \\
--.--\end{array}\right|$ & $\begin{array}{l}35.0 \\
40.2 \\
45.2 \\
50.9\end{array}$ & $\begin{array}{l}33.7 \\
38.7 \\
43.6 \\
49.1\end{array}$ & $\begin{array}{r}8.6 \\
9.9 \\
11.2 \\
\hdashline\end{array}$ & $\begin{array}{r}.3 \\
.4 \\
.4 \\
.5\end{array}$ & $\begin{array}{r}8,600 \\
9,880 \\
11,120 \\
12,620\end{array}$ \\
\hline $\mathbf{K}$ & $\begin{array}{l}\text { Loc. 117, sec. 24, T. } 6 \mathrm{~S} ., \text { R. } 14 \mathrm{~W}_{\text {; }} \\
\text { uppermost coal exposed in beach } \\
\text { cliff at mouth of Bidark1 Creek } \\
\text { (Bed 5). }\end{array}$ & ....do do & $\begin{array}{l}\text { Subbltuminous } \\
\text { C }(9,200) \text {. }\end{array}$ & $C-61955$ & 14. 9 & $\begin{array}{l}\mathbf{A} \\
\mathbf{B} \\
\mathbf{C} \\
\mathbf{D}\end{array}$ & 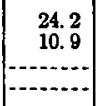 & $\begin{array}{l}34.9 \\
41.1 \\
46.1 \\
51.4\end{array}$ & $\begin{array}{l}33.1 \\
38.8 \\
43.6 \\
48.6\end{array}$ & $\begin{array}{r}7.8 \\
9.2 \\
10.3 \\
\end{array}$ & $\begin{array}{l}.3 \\
.3 \\
.4 \\
.4\end{array}$ & $\begin{array}{r}8,490 \\
9,980 \\
11,200 \\
12,480\end{array}$ \\
\hline L & $\begin{array}{l}\text { Loc. 118, sec. } 24, \text { T. } 6 \text { S., R. } 14 \mathrm{~W} . ; \\
\text { Cooper bed } 23 \text { feet inside portal } \\
\text { No.2 of Homer Coal Corp. mine. }\end{array}$ & $\begin{array}{l}\text { A. L. Toenges } \\
\text { and T. R. } \\
\text { Jolly, } 1946 .\end{array}$ & $\begin{array}{l}\text { Subbituminous } \\
\text { B }(10,450)\end{array}$ & C-61783 & 9.8 & $\begin{array}{l}\mathbf{A} \\
\mathbf{B} \\
\mathbf{C} \\
\mathbf{D}\end{array}$ & $\begin{array}{r}16.5 \\
7.5 \\
-. . . \\
\end{array}$ & $\begin{array}{l}30.3 \\
33.6 \\
36.3 \\
\mathbf{4 2 . 5}\end{array}$ & $\begin{array}{l}41.1 \\
45.5 \\
49.2 \\
57.5\end{array}$ & $\begin{array}{l}12.1 \\
13.4 \\
14.5 \\
-\cdots\end{array}$ & $\begin{array}{l}.4 \\
.5 \\
.5 \\
.6\end{array}$ & $\begin{array}{r}9,020 \\
9,990 \\
10,800 \\
12,620\end{array}$ \\
\hline $\mathbf{M}$ & $\begin{array}{l}\text { Loc. } 118 \text {, sec. } 24, \text { T. } 6 \mathrm{~S} ., \mathrm{R} .14 \mathrm{~W} . ; \\
\text { composite of three samples from } \\
\text { Cooper bed in Bluft Point mine. }\end{array}$ & $\begin{array}{l}\text { B. W. Dyer, } \\
\text { 1921. }\end{array}$ & $\begin{array}{l}\text { Subbituminous } \\
\mathrm{C}(\theta, 300)\end{array}$ & 81609 & ......... & $\begin{array}{l}\mathrm{A} \\
\mathbf{C} \\
\mathbf{D}\end{array}$ & 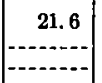 & $\begin{array}{l}38.1 \\
48.7 \\
55.1\end{array}$ & $\begin{array}{l}31.2 \\
39.5 \\
44.9\end{array}$ & $\begin{array}{r}9.1 \\
11.8 \\
\hdashline .9\end{array}$ & $\begin{array}{l}.3 \\
.4 \\
.5\end{array}$ & $\begin{array}{r}8,380 \\
10.690 \\
12,100\end{array}$ \\
\hline $\mathbf{N}$ & $\begin{array}{l}\text { Loc. 141, sec. } 26 \text {, T. } 5 \text { S., R. } 12 \mathrm{~W} \text {.; } \\
\text { outcrop in beach bluff. }\end{array}$ & E. H. Cobb 1951 & $\begin{array}{l}\text { Subbituminous } \\
\mathrm{C}(9,150)\end{array}$ & D-70511 & 11.3 & $\begin{array}{l}\mathbf{A} \\
\mathbf{B} \\
\mathbf{C} \\
\mathbf{D}\end{array}$ & \begin{tabular}{r}
24.1 \\
14.4 \\
\hdashline.- \\
\hdashline..- \\
\end{tabular} & $\begin{array}{l}35.1 \\
39.6 \\
46.2 \\
52.2\end{array}$ & $\begin{array}{l}32.1 \\
36.2 \\
42.4 \\
47.8\end{array}$ & $\begin{array}{r}8.7 \\
9.8 \\
11.4 \\
--\end{array}$ & $\begin{array}{l}.2 \\
.3 \\
.3 \\
.3\end{array}$ & $\begin{array}{r}8,280 \\
9,340 \\
10.900 \\
12,310\end{array}$ \\
\hline 0 & $\begin{array}{l}\text { Loc. 143, sec. 25, T. } 5 \text { S., R. } 12 \mathrm{~W} \text {.; } \\
\text { outcrop of bed } B \text { (Curtis seam) } \\
\text { in beach bluff. }\end{array}$ & .....do do . . . & $\begin{array}{l}\text { Subbituminous } \\
\mathbf{C}(8,950)\end{array}$ & D-71164 & 11.0 & $\begin{array}{l}\mathbf{A} \\
\mathbf{B} \\
\mathbf{O} \\
\mathbf{D}\end{array}$ & \begin{tabular}{r}
22.6 \\
13.0 \\
\hdashline-0 \\
\hdashline.-- \\
\end{tabular} & $\begin{array}{l}33.3 \\
37.4 \\
43.0 \\
55.0\end{array}$ & $\begin{array}{l}27.1 \\
30.5 \\
35.1 \\
45.0\end{array}$ & $\begin{array}{l}17.0 \\
18.1 \\
21.9\end{array}$ & $\begin{array}{l}.4 \\
.5 \\
.6 \\
.7\end{array}$ & $\begin{array}{r}7,350 \\
8,260 \\
9,490 \\
12,160\end{array}$ \\
\hline $\mathbf{P}$ & $\begin{array}{l}\text { Loc. 145, sec. } 25, T .5 \text { S., R. } 12 W_{\text {; }} \text {, } \\
\text { outcrop of bed } \mathrm{C} \text { in beach bluff. }\end{array}$ & (...do do . & $\begin{array}{l}\text { Subbituminous } \\
\mathbf{C}(8,900)\end{array}$ & D-70512 & 11.9 & $\begin{array}{l}\mathbf{A} \\
\mathbf{B} \\
\mathbf{C} \\
\mathbf{D}\end{array}$ & \begin{tabular}{r}
22.6 \\
12.1 \\
\hdashline \\
\end{tabular} & $\begin{array}{l}31.7 \\
36.0 \\
40.9 \\
54.7\end{array}$ & $\begin{array}{l}26.2 \\
29.8 \\
33.9 \\
45.3\end{array}$ & \begin{tabular}{l}
18.5 \\
22.1 \\
25.2 \\
\hdashline..-
\end{tabular} & $\begin{array}{l}.3 \\
: 3 \\
.3 \\
.3 \\
.5\end{array}$ & $\begin{array}{r}6,980 \\
7,920 \\
9,010 \\
12,040\end{array}$ \\
\hline QI & $\begin{array}{l}\text { Loc. } 150 \text {, sec. 19, T. } 5 \text { S., R. } 11 \mathrm{~W} \text {; } \\
\text { outcrop in beach bluff. }\end{array}$ & $\ldots$ do & Lignite $(7,900) \ldots$ & D-70513 & 19.8 & $\begin{array}{l}\mathbf{A} \\
\mathbf{B} \\
\mathbf{C} \\
\mathbf{D}\end{array}$ & \begin{tabular}{|r|}
30.3 \\
13.1 \\
\hdashline..- \\
\end{tabular} & $\begin{array}{l}33.3 \\
41.5 \\
47.8 \\
52.4\end{array}$ & $\begin{array}{l}30.3 \\
37.8 \\
43.4 \\
47.6\end{array}$ & $\begin{array}{l}6.1 \\
7.6 \\
8.8\end{array}$ & $\begin{array}{l}.1 \\
.1 \\
.2 \\
.2\end{array}$ & $\begin{array}{r}7,400 \\
9,230 \\
10,630 \\
11,650\end{array}$ \\
\hline $\mathbf{R}$ & $\begin{array}{l}\text { Loc. 153, sec. 17, T. } 5 \text { S., R. } 11 \text { W.; } \\
\text { outorop in beach bluff. }\end{array}$ & -.do do & $\begin{array}{l}\text { Subbituminous } \\
\mathrm{C}(8,800)\end{array}$ & D-71165 & 14.1 & $\begin{array}{l}\mathbf{A} \\
\mathbf{B} \\
\mathbf{C} \\
\mathbf{D}\end{array}$ & $\begin{array}{r}23.4 \\
10.8 \\
\\
\hdashline\end{array}$ & $\begin{array}{l}33.1 \\
38.5 \\
43.2 \\
54.7\end{array}$ & $\begin{array}{l}27.3 \\
31.9 \\
35.7 \\
45.3\end{array}$ & $\begin{array}{l}16.2 \\
18.8 \\
21.1\end{array}$ & $\begin{array}{l}.4 \\
.5 \\
.5 \\
.7\end{array}$ & $\begin{array}{r}7,290 \\
8,480 \\
9,510 \\
12,050\end{array}$ \\
\hline
\end{tabular}

1 In accordance with American Society for Testing Materlals, Standard speciflcations for classification of coal by rank (A.S.T.M. Designation: D-388-38, A.8.A.M .20.11938): 1939 Book of A.S.T.M. Standards, pt. 3, p. 1-6. 
same locality near Bidarki Creek on a permit granted under the new coal-leasing law enacted in 1914. This law provided for the granting of permits to mine coal in tracts of 10 acres or less. No records of production are available, except that in 1915 this operation, known as the Bluff Point mine, was the largest of several operating under similar permits that together produced about 1,400 tons. Some production continued at the Bluff Point mine until 1923, the operation having been changed from a permit to a lease in 1920. Records show that about 1,200 tons was mined in $1921,2,700$ tons in 1922 , and 700 tons in 1923. No records were found to indicate that the mine was operated between 1924 and 1945 .

In 1946 the Bluff Point mine was taken over by the Homer Coal Corp. A new camp was constructed, and underground development started. Some development work and incidental coal production were continued until 1951, when an extensive engineering study, including the drilling of nine diamond-drill holes, was made in an effort to block out reserves of stripping coal. No production has been reported from this property since 1951; the only later production from the Homer district was from a few small stripping operations near Homer.

The total commercial production of coal in the Homer district is not known, but it probably does not exceed a few thousand tons. In addition, local residents have for many years used coal picked up on the beach or dug from convenient outcrops farther inland.

\section{COAL RESERVES}

Indicated coal reserves in the Homer district are estimated to total about 400 million tons in beds 2 feet or more in thickness. Of this amount, about 300 million tons is in beds more than 2.5 feet thick, and more than 50 million tons is in beds more than 5 feet thick. The estimated reserves are, for the most part, under less than 1,000 feet of cover and within half a mile of the outcrop. In table 2 the reserves are reported by township and bed and range of thickness. Owing to the small amount of underground development, none of the reserves are classed as measured. It is highly probable that many of the coal beds extend much more than half a mile from the outcrop, and that other beds that are nowhere exposed underlie many inland areas. Owing to the lack of data on the number, extent, and thickness of such concealed beds, no attempt was made to compute inferred reserves in these areas. The results of this investigation suggest that all but the extreme northern and northeastern parts of the district, or an area of about 750 square miles, probably is underlain by coal beds 2 feet or more in thickness. If so, the potential reserves of the district may amount to several billion tons. 
In table 2 and in the following descriptions of coal beds by townships, certain coal beds, mainly those that were identified at several localities, have either been assigned names or given numbers or letter designations.

TABLE 2.-Estimated coal reserves of the Homer district, by individual beds, Kenai coal field, Alaska

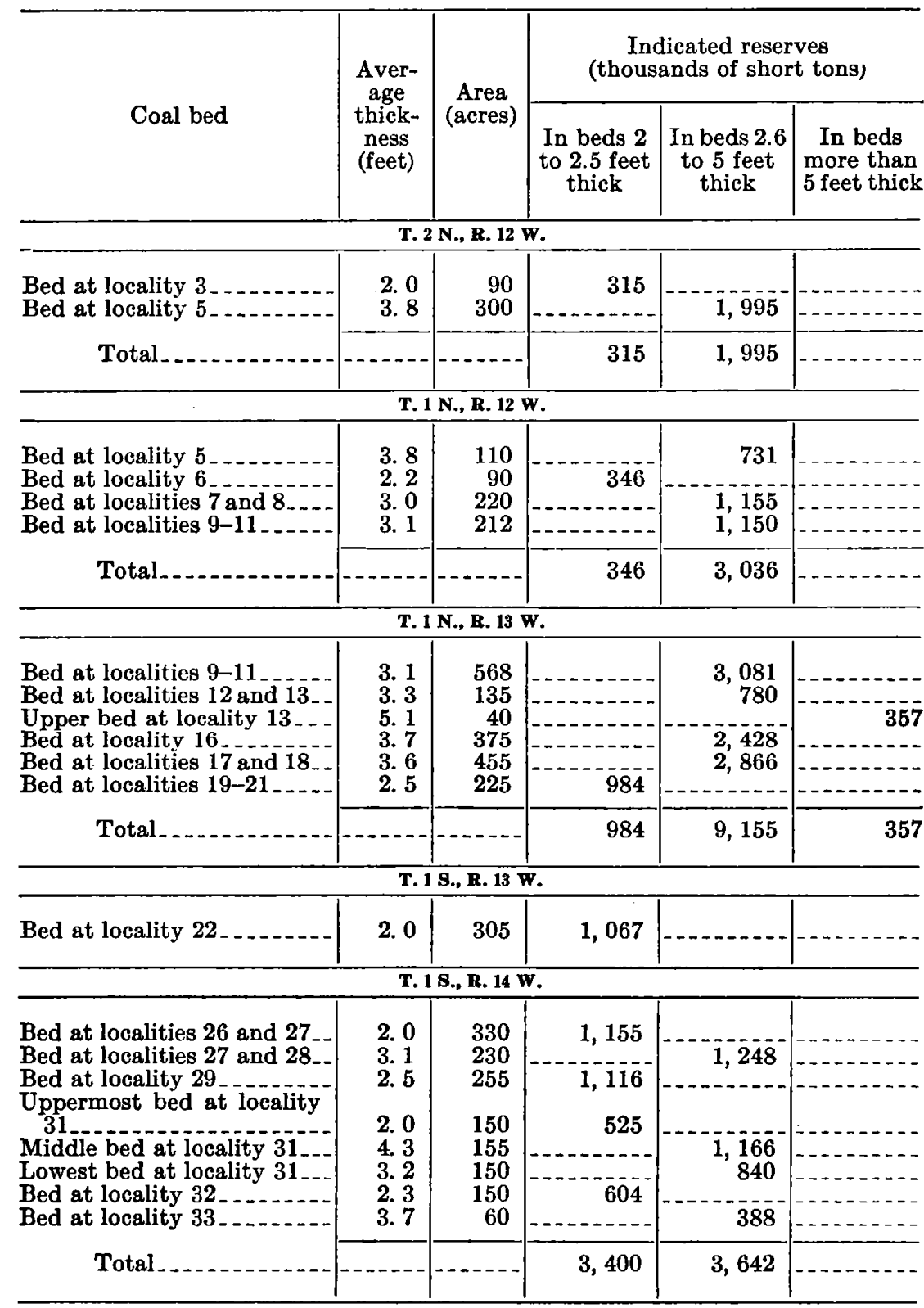


TABLE 2.-Estimated coal reserves of the Homer district, by individual beds, Kenai coal field, Alaska-Continued

\begin{tabular}{c|c|c|c|c} 
Coal bed & $\begin{array}{c}\text { Aver- } \\
\text { age } \\
\text { thick- } \\
\text { ness } \\
\text { (feet) }\end{array}$ & $\begin{array}{c}\text { Area } \\
\text { (acres) }\end{array}$ & $\begin{array}{c}\text { Indicated reserves } \\
\text { (thousands of short tons) }\end{array}$ \\
\cline { 3 - 5 } & $\begin{array}{c}\text { In beds 2 } \\
\text { to 2.5 feet } \\
\text { thick }\end{array}$ & $\begin{array}{c}\text { In beds 2.6 } \\
\text { to 5 feet } \\
\text { thick }\end{array}$ & $\begin{array}{c}\text { In beds } \\
\text { more than feet thick } \\
5\end{array}$ \\
\hline
\end{tabular}

T. 2 S., R. 13 W. (Unsurveyed)

Bed at locality 37

Bed at localities 38-43

Bed at locality 45

Bed at locality 46

Bed at locality 48

Bed at locality 49

Bed at locality 51

Upper bed at locality $52-1$

Lower bed at locality $\mathbf{5 2}$

\begin{tabular}{|c|c|c|c|c|}
\hline $\begin{array}{l}\text { 3. } 3 \\
\text { 3. } 4 \\
2.9 \\
\text { 5. } 0 \\
2.5 \\
2.0 \\
2.5 \\
4.0 \\
4.1\end{array}$ & $\begin{array}{r}320 \\
1,400 \\
300 \\
300 \\
300 \\
300 \\
300 \\
300 \\
300\end{array}$ & $\begin{array}{r}1,312 \\
1,050 \\
1,312\end{array}$ & $\begin{array}{r}1,848 \\
8,330 \\
1,522 \\
2,625 \\
2,100 \\
2,152\end{array}$ & 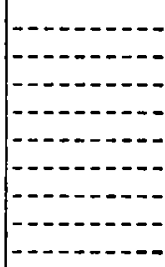 \\
\hline & $-1-1$ & 3,674 & 18,577 & \\
\hline
\end{tabular}

T. 2 S., R. 14 W.

Bed at locality $\mathbf{3 3}$

Bed at localities 34 and 35

Bed at locality 36

Bed at locality 54

Bed at locality 55

Bed at locality $\mathbf{5 6}$

Bed at locality 57 .

Bed at locality 59

Bed at localities 59 and 60

Lower bed at locality 60

Bed at locality 64

Total

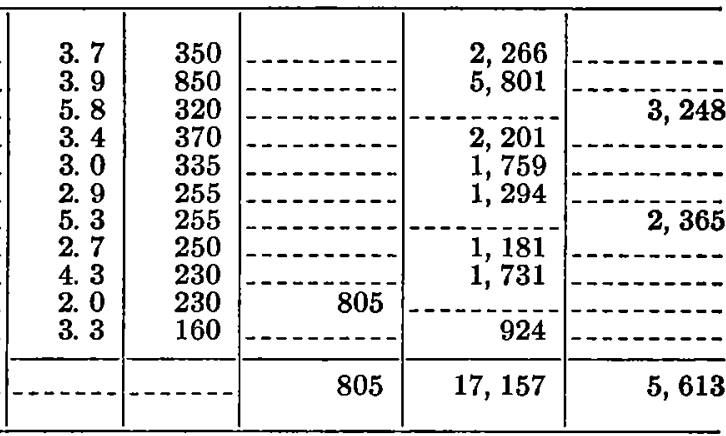

T. 3 S., R. 10 W. (Unsurveyed)

\begin{tabular}{|c|c|c|c|c|c|}
\hline $\begin{array}{l}\text { Upper bed at locality } 177-- \\
\text { Lower bed at locality } 177 .-\end{array}$ & $\begin{array}{l}\text { 2. } 0 \\
\text { 2. } 6\end{array}$ & $\begin{array}{l}320 \\
320\end{array}$ & 1,120 & 1,456 & \\
\hline Total & & $\ldots \ldots$ & 1,120 & 1,456 & \\
\hline
\end{tabular}

T. 3 S., R. 14 W.

\begin{tabular}{|c|c|c|c|c|c|}
\hline $\begin{array}{l}\text { Bed at locality } 64 \\
\text { Bed at locality } 65 \\
\text { Bed at locality } 67 \\
\text { Bed at locality } 68 \\
\text { Bed at localities } 69 \text { and } 70 \\
\text { Lower bed at locality } 70 \\
\text { Bed at locality } 71\end{array}$ & $\begin{array}{l}\text { 3. } 3 \\
\text { 2. } 4 \\
\text { 3. } 3 \\
\text { 3. } 4 \\
\text { 4. } 5 \\
\text { 3. } 3 \\
\text { 2. } 8\end{array}$ & $\begin{array}{r}80 \\
270 \\
295 \\
270 \\
265 \\
280 \\
95\end{array}$ & 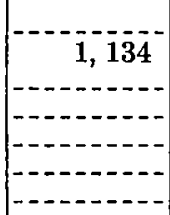 & \begin{tabular}{r}
462 \\
\hdashline 1,704 \\
1,606 \\
2,087 \\
1,617 \\
465
\end{tabular} & \\
\hline Total_ & & & 1,134 & 7,941 & \\
\hline
\end{tabular}


TABLE 2.-Estimated coal reserves of the Homer district, by individual beds, Kenai coal field, Alaska-Continued

\begin{tabular}{l|c|c|c|c|c}
\hline Coal bed & $\begin{array}{c}\text { Aver- } \\
\text { age } \\
\text { thick- } \\
\text { ness } \\
\text { (feet) }\end{array}$ & $\begin{array}{c}\text { Area } \\
\text { (acres) }\end{array}$ & \multicolumn{3}{|c|}{$\begin{array}{c}\text { Indicated reserves } \\
\text { (thousands of short tons) }\end{array}$} \\
\cline { 3 - 6 } & $\begin{array}{c}\text { In beds 2 } \\
\text { to 2.5 feet } \\
\text { thick }\end{array}$ & $\begin{array}{c}\text { In beds 2.6 } \\
\text { to 5 feet } \\
\text { thick }\end{array}$ & $\begin{array}{c}\text { In beds } \\
\text { more than } \\
5 \text { feet thick }\end{array}$ \\
\hline
\end{tabular}

T. 4 S., R. 10 W. (Unsurveyed)

Uppermost bed at locality 171

Bed at locality $17 \overline{1}$

Lowest bed at locality $17 \overline{1}$.

Uppermost bed at locality 172

Beds at locality 172

Lowest bed at locality 172

Uppermost bed at locality 173

Beds at locality 173

Lowest bed at locality 173 .

Bed at locality 174

Uppermost bed at locality 175

Beds at locality 175

Lowest bed at locality 175

Uppermost bed at locality 176

Beds at locality 176

Lowest bed at locality 176

Total
4. 8

5. 1

2. 5

2. 6

3. 0

4. 2

3. 7

3. 8

2. 3

2. 0

2. 1

4. 1

4. 4

3. 0

3. 3

3. 7

2. 0

2. 0

4. 9

5. 4

2. 8

2. 5

4. 0

5. 1

4. 6

3. 5

2. 1

4. 0

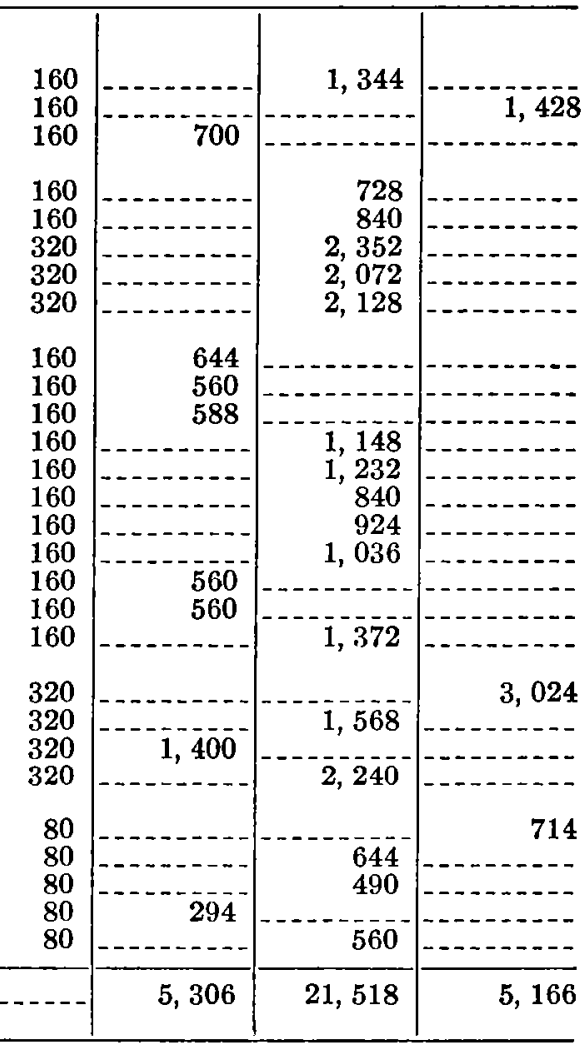

T. 4 S., R. 11 W. (Unsurveyed)

Bed L at localities 160-167.

Bed $\mathrm{K}$ at localities 160-166.

Bed J at localities 160-163.

Bed $M$ at localities 163-167.

Bed above bed $L$ at locality 167

Bed above bed $M$ at localiities 166 and 167

Bed above bed $T$ at locality 168.

Bed T at localities $16 \overline{8}$ and 169

Bed U at locality 169

489961- $59-4$

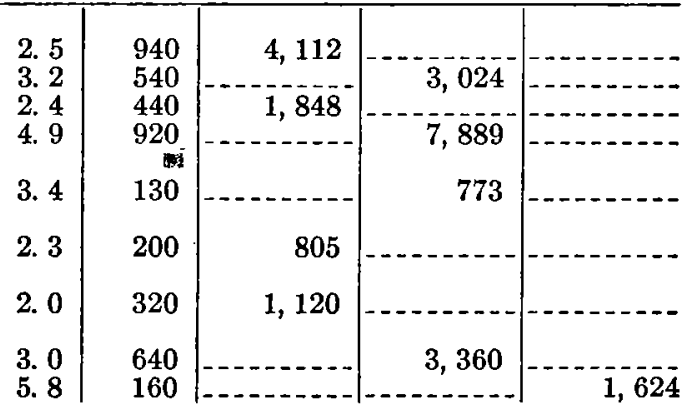


TABLE 2.-Estimated coal reserves of the Homer district, by individual beds, Kenai coal field, Alaska-Continued

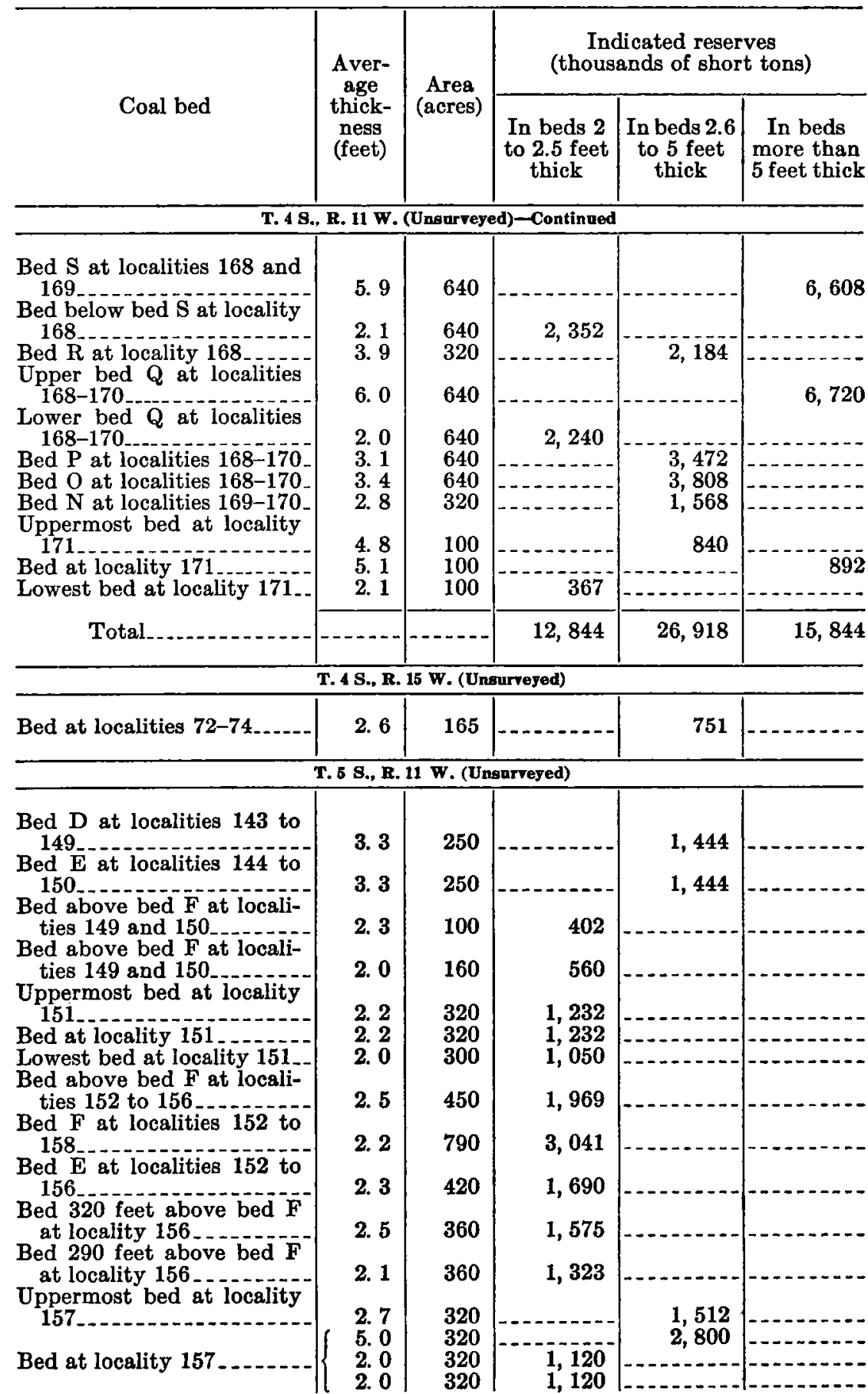


TABLE 2.-Estimated coal reserves of the Homer district, by individual beds, Kenai coal field, Alaska-Continued

\begin{tabular}{|c|c|c|c|c|c|}
\hline \multirow{2}{*}{ Coal bed } & \multirow{2}{*}{$\begin{array}{l}\text { Aver- } \\
\text { age } \\
\text { thick- } \\
\text { ness } \\
\text { (feet) }\end{array}$} & \multirow{2}{*}{$\begin{array}{c}\text { Area } \\
\text { (acres) }\end{array}$} & \multicolumn{3}{|c|}{$\begin{array}{c}\text { Indicated reserves } \\
\text { (thousands of short tons) }\end{array}$} \\
\hline & & & $\begin{array}{l}\text { In beds } 2 \\
\text { to } 2.5 \text { feet } \\
\text { thick }\end{array}$ & $\begin{array}{l}\text { In beds } 2.6 \\
\text { to } 5 \text { feet } \\
\text { thick }\end{array}$ & $\begin{array}{l}\text { In beds } \\
\text { more than } \\
5 \text { feet thick }\end{array}$ \\
\hline \multicolumn{6}{|c|}{ T. 5 S., R. 11 W. (Unsurveyed)-Continued } \\
\hline Bed 300 feet above bed $F$ & 2. 2 & 320 & 1,232 & & \\
\hline Uppermost bed at locality & 2. 5 & 320 & 1,400 & & \\
\hline $\begin{array}{l}\text { Bed at locality } 158 \\
\text { Bed } J \text { at localities } 158 \text { and }\end{array}$ & 3. 0 & 320 & 1,700 & 1,680 & \\
\hline Bed below bed $\mathrm{J}$ at locality & 3. 2 & 580 & raco & 3,248 & \\
\hline Lowest bed at locality 158 & $\begin{array}{l}2.0 \\
\text { 4. } 4\end{array}$ & $\begin{array}{l}320 \\
320\end{array}$ & 1,120 & 2,464 & \\
\hline Bed I at localit & 2.0 & 170 & 595 & & \\
\hline $\begin{array}{l}\text { Bed } G \text { at locality } 159 \\
\text { Bed } L \text { at localities } 160 \text { to }\end{array}$ & 2. 1 & 230 & 845 & $-\ldots .$. & \\
\hline Bed $\mathrm{K}$ at localities 160 to & 2. 5 & 160 & 700 & & \\
\hline $166_{-}$ & 3. 2 & 160 & & 896 & \\
\hline Bed $J$ at localities 160 to & 2. 4 & 160 & 672 & & \\
\hline Bed I at localities 160 and & 2. 1 & 200 & 735 & & \\
\hline $\begin{array}{l}\text { Bed } \mathrm{H} \text { at locality } 161 \\
\text { Bed below bed } H \text { at locality }\end{array}$ & 2. 0 & 120 & 420 & & \\
\hline Total. & & $\cdots$ & 24,453 & 15,488 & \\
\hline \multicolumn{6}{|c|}{ T. 5 S., R. 12 W. } \\
\hline $\begin{array}{l}\text { Upper bed at locality } 133 \\
\text { Middle bed at locality } 133\end{array}$ & $\begin{array}{l}\text { 2. } 0 \\
\text { 2. } 2\end{array}$ & $\begin{array}{l}320 \\
320\end{array}$ & $\begin{array}{l}1,120 \\
1,232\end{array}$ & & \\
\hline Lowest bed at locality 133 & $\begin{array}{l}\text { 2. } 7 \\
\text { 3. } 2 \\
?\end{array}$ & $\begin{array}{l}320 \\
320 \\
390\end{array}$ & $(1,202$ & $\begin{array}{l}1, \overline{5} 12 \\
1,792\end{array}$ & \\
\hline $\begin{array}{l}\text { Lower bed at locality } 134 \\
\text { Bed at locality } 135 \\
\text { Bed at localities } 138 \text { and } 139\end{array}$ & $\begin{array}{l}2.7 \\
2.6 \\
2.7\end{array}$ & $\begin{array}{l}320 \\
320 \\
320\end{array}$ & & $\begin{array}{l}1,512 \\
1,456 \\
1,512\end{array}$ & \\
\hline $\begin{array}{l}\text { Bed } A \text { at localities } 140 \text { to } \\
142\end{array}$ & 2.9 & 310 & & 1,573 & \\
\hline $\begin{array}{l}\text { Lower bed at locality } 140 \\
\text { Bed } B \text { at localities } 142 \text { and }\end{array}$ & 2. 1 & 220 & 808 & & \\
\hline 143 - & 4. 3 & 390 & & 2,935 & \\
\hline $\begin{array}{l}\text { Bed } C \text { at localities } 143 \text { to } \\
146\end{array}$ & 4. 2 & 380 & & 2,793 & \\
\hline $\begin{array}{l}\text { Bed } D \text { at localities } 143 \text { to } \\
149\end{array}$ & 3. 3 & 770 & & 4,447 & \\
\hline Bed E at localities 144 to & ? ? & 等 & & $1,-120$ & \\
\hline Bed $F$ at localities 144 to & 3. 3 & 300 & & $2,0 \gamma y$ & \\
\hline Bed above bed F at locali- & 3. 4 & & & 1,190 & \\
\hline $\begin{array}{l}\text { ties } 144 \text { to } 146 \\
\text { Bed above bed F at locali- }\end{array}$ & 2. 0 & 60 & 210 & & \\
\hline $\begin{array}{l}\text { Bed above bed } \mathrm{F} \text { at } 10 \\
\text { ties } 144 \text { to } 147\end{array}$ & 2. 5 & 220 & 962 & & \\
\hline intol & & & 4,332 & 22,801 & \\
\hline
\end{tabular}


TABLE 2.-Estimated coal reserves of the Homer district, by individual beds, Kenai coal field, Alaska-Continued

\begin{tabular}{|c|c|c|c|c|c|}
\hline \multirow{2}{*}{ Coal bed } & \multirow{2}{*}{$\begin{array}{c}\text { Aver- } \\
\text { age } \\
\text { thick- } \\
\text { ness } \\
\text { (feet) }\end{array}$} & \multirow{2}{*}{$\begin{array}{c}\text { Area } \\
\text { (acres) }\end{array}$} & \multicolumn{3}{|c|}{$\begin{array}{c}\text { Indicated reserves } \\
\text { (thousands of short tons) }\end{array}$} \\
\hline & & & $\begin{array}{c}\text { In beds } 2 \\
\text { to } 2.5 \text { feet } \\
\text { thick }\end{array}$ & $\begin{array}{c}\text { In beds } 2.6 \\
\text { to } 5 \text { feet } \\
\text { thick }\end{array}$ & $\begin{array}{l}\text { In beds } \\
\text { more than } \\
5 \text { feet thick }\end{array}$ \\
\hline
\end{tabular}

T. 5 S., R. 13 W.

Bed at locality 119

Bed at locality 120

Bed at locality 92

Woodman bed at localities 126 to 130

Bed below Woodman at localities 126 to 130

Do

Fletcher bed at localities 127 to 130

Bed below Fletcher at localities 128 to 130

Bed at locality 131

$$
\text { Total }
$$

\begin{tabular}{|c|c|c|c|c|}
\hline $\begin{array}{l}2.6 \\
2.7 \\
\text { 3. } 9\end{array}$ & $\begin{array}{l}320 \\
320 \\
120\end{array}$ & 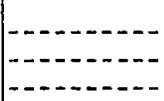 & $\begin{array}{r}1,456 \\
1,512 \\
819\end{array}$ & 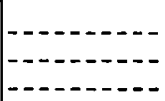 \\
\hline 2. 7 & 1,845 & 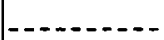 & 8,718 & - \\
\hline $\begin{array}{l}2.3 \\
2.2\end{array}$ & $\begin{array}{l}1,845 \\
1,845\end{array}$ & $\begin{array}{l}7,426 \\
7,103\end{array}$ & 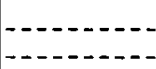 & - - - - - \\
\hline 2. 5 & 625 & 2,734 & ---------1 & ------ \\
\hline $\begin{array}{l}\text { 2. } 9 \\
\text { 5. } 6\end{array}$ & $\begin{array}{l}400 \\
320\end{array}$ & - & 2,030 & $\cdots \overline{3}, \overline{136}$ \\
\hline$\ldots$ &.----- & 17,263 & 14,535 & 3,136 \\
\hline
\end{tabular}

T. 5 S., R. 14 W.

Bed at locality 92

3. 9

30

$\mid$

T. 5 S., R. 15 W.

\begin{tabular}{|c|c|c|c|c|c|}
\hline $\begin{array}{l}\text { Bed at locality } 75 \\
\text { Bed at localities } 76 \text { and } 77 \\
\text { Upper bed at locality } 78 \\
\text { Lower bed at locality } 78 \\
\text { Bed at localities } 79 \text { and } 80 \\
\text { Bed at localities } 80 \text { and } 81 \\
\text { Upper bed at locality } 81 \\
\text { Bed at locality } 82\end{array}$ & $\begin{array}{l}\text { 2. } 0 \\
\text { 3. } 1 \\
\text { 3. } 2 \\
\text { 2. } 8 \\
\text { 3. } 6 \\
\text { 3. } 2 \\
\text { 3. } 7 \\
\text { 3. } 3\end{array}$ & $\begin{array}{r}50 \\
215 \\
215 \\
265 \\
230 \\
175 \\
55 \\
50\end{array}$ & 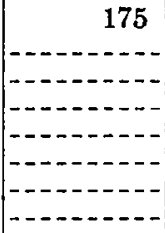 & $\begin{array}{r}1,166 \\
1,204 \\
1,298 \\
1,449 \\
980 \\
356 \\
289\end{array}$ & 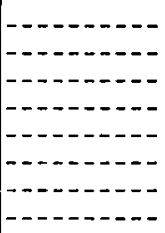 \\
\hline Total & & $\ldots \ldots$ & 175 & 6,742 & \\
\hline
\end{tabular}

T. 6 S., R. 12 W.

\begin{tabular}{l|l|r|r|r|r}
\hline Bed at locality $136 \ldots . . . .-2.2$ & 320 & 1,232 & & \\
\hline
\end{tabular}


TABLE 2.-Estimated coal reserves of the Homer district, by individual beds, Kenai coal field, Alaska-Continued

\begin{tabular}{l|c|c|c|c|c}
\hline & $\begin{array}{c}\text { Aver- } \\
\text { age } \\
\text { thick- } \\
\text { ness } \\
\text { (feet) }\end{array}$ & $\begin{array}{c}\text { Area } \\
\text { (acres) }\end{array}$ & \multicolumn{3}{|c}{$\begin{array}{c}\text { Indicated reserves } \\
\text { (thousands of short tons) }\end{array}$} \\
\cline { 3 - 5 } & & $\begin{array}{c}\text { In beds 2 } \\
\text { to 2.5 feet } \\
\text { thick }\end{array}$ & $\begin{array}{c}\text { In beds 2.6 } \\
\text { to 5 feet } \\
\text { thick }\end{array}$ & $\begin{array}{c}\text { In beds } \\
\text { more than } \\
5 \text { feet thick }\end{array}$ \\
\hline
\end{tabular}

T. 6 S., R. 13 W.

Bed at locality 92

Cabin bed at localities 117 and 123

Cabin bed at locality 122

Beds at locality 122

Lowest bed at locality 122 .

Bed below Cabin bed at locality 123 .

Beds at locality 123

Lowest bed at locality 123 .

Upper bed at locality 124

Lower bed at locality 124

Woodman bed, at localities $126-130$

Bed below Woodman bed at localities 126-130.

Do.

Beds at locality 126

Fletcher bed, at localities 127-130.

Bed below Fletcher bed at localities 128-130.

Total

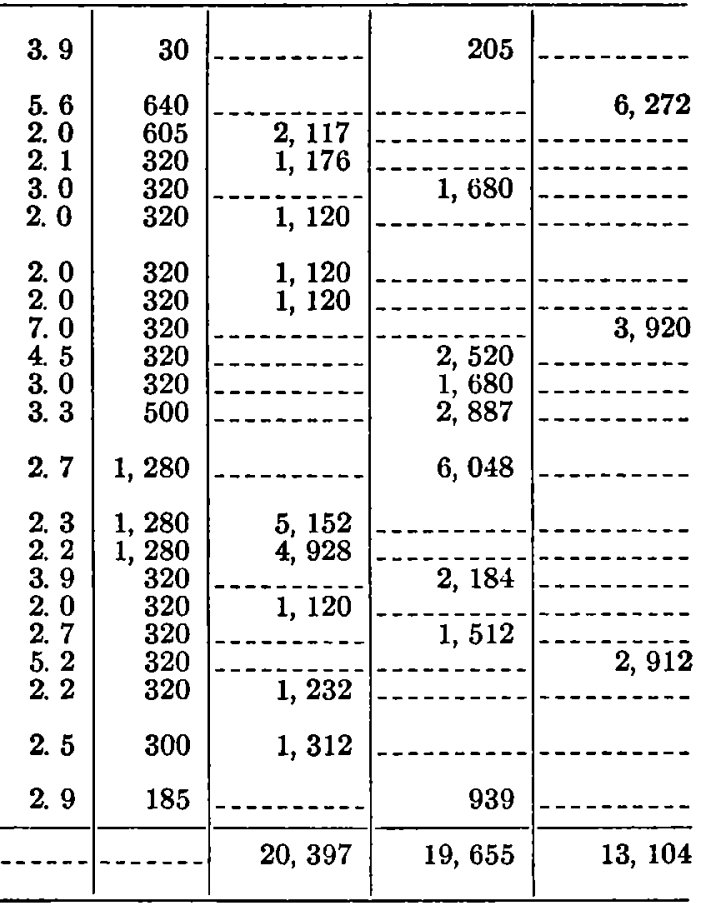

T. 6 S., R. 14 W.

Upper bed at locality 84

Lower bed at locality 84

Upper bed at locality $\mathbf{8 6}$

Middle bed at locality 86

Lower bed at locality 86 .

Bed at locality 87

Bed at localities $8 \overline{8}-90$

Lower bed at locality $\mathbf{8 8}$

Bed at localities 89 and 90

Lofgren bed at localities 93 to 106

Cooper bed at localities 107-118.

Upper bed at locality 107

Bed below Cooper at locality 113

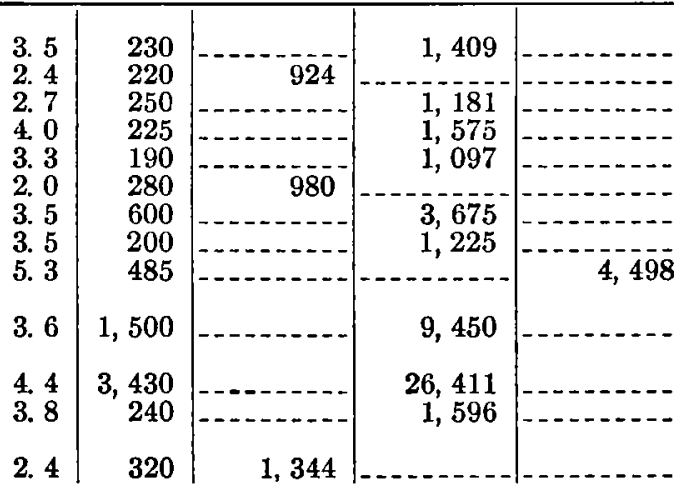


TABLE 2.-Estimated coal reserves of the Homer district, by individual beds, Kenai coal field, Alaska-Continued

\begin{tabular}{|c|c|c|c|c|c|}
\hline \multirow[b]{2}{*}{ Coal bed } & \multirow{2}{*}{$\begin{array}{c}\text { Aver- } \\
\text { age } \\
\text { thick- } \\
\text { ness } \\
\text { (feet) }\end{array}$} & \multirow{2}{*}{$\begin{array}{c}\text { Area } \\
\text { (acres) }\end{array}$} & \multicolumn{3}{|c|}{$\begin{array}{l}\text { Inaicated reserves } \\
\text { (thousands of short tons) }\end{array}$} \\
\hline & & & $\begin{array}{l}\text { In beds } 2 \\
\text { to } 2.5 \text { feet } \\
\text { thick }\end{array}$ & $\begin{array}{l}\text { In beds } 2.6 \\
\text { to } 5 \text { feet } \\
\text { thick }\end{array}$ & $\begin{array}{l}\text { In beds } \\
\text { more than } \\
5 \text { feet thick }\end{array}$ \\
\hline \multicolumn{6}{|c|}{ T. 6 S., R. 14 W.-Continued } \\
\hline $\begin{array}{l}\text { Cabin bed at localities } 117 \\
\text { and } 123 \\
\text { Bed } 140 \text { feet below Cabin } \\
\text { bed at locality } 117 \\
\text { Bed } 400 \text { feet above bed } 5 \text { at } \\
\text { locality } 117 \\
\text { Bed } 5 \text { at locality } 117 \\
\text { Bed } 4 \text { at locality } 117\end{array}$ & $\begin{array}{l}3.6 \\
2.7 \\
2.2\end{array}$ & $\begin{array}{l}320 \\
160 \\
160\end{array}$ & 616 & $\begin{array}{r}2,016 \\
756\end{array}$ & 6,272 \\
\hline Total .... & $-\ldots-1$ & $-\ldots-1-1$ & 5,040 & 50,391 & 10,770 \\
\hline \multicolumn{6}{|c|}{ T. 6 S., R. 15 W. } \\
\hline $\begin{array}{l}\text { Bed at locality } 83 \\
\text { Upper bed at locality } 84 \\
\text { Lower bed at locality } 84\end{array}$ & $\begin{array}{l}\text { 3. } 4 \\
\text { 3. } 5 \\
\text { 2. } 4\end{array}$ & $\begin{array}{l}55 \\
50 \\
50\end{array}$ & 210 & $\begin{array}{l}327 \\
306\end{array}$ & 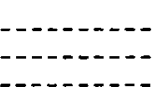 \\
\hline Total & $\ldots \ldots$ & $\ldots \ldots$ & 210 & 633 & \\
\hline $\begin{array}{l}\text { Total reserves of each } \\
\text { thickness range }\end{array}$ & & & 104,097 & 242,596 & 53,990 \\
\hline Total reserves_-_- & $-\ldots$ & $\ldots$ & & - & 400,683 \\
\hline
\end{tabular}

In computing the indicated reserves, the area underlain by a given coal bed was determined by assuming that an outcrop establishes continuity for half a mile in all directions, except where there is evidence that the bed is terminated at a shorter distance by thinning, faulting, or erosion. The areas of the few beds that were traced for more than a mile along the outcrop were determined by assuming that the bed extended back from the outcrop for a distance equal to half the known length of outcrop. Beds that thin to less than 2 feet at points less than a mile apart were assumed to underlie a semicircular area with a radius equal to half the length of outcrop within the thickness limits. Reserves of beds that dip below sea level were not assumed to be limited by sea level, but no reserves were computed beyond the high-tide line. Also, several beds that are exposed only below high-tide level were not included in the computations. No allowance for burned coal was made in the reserve computations, except that beds represented only by burned outcrops were not included.

The thickness figures used in computing reserves are the weighted averages of all measurements made of each bed, determined by the 
method prescribed by the Geological Survey (Averitt, Berryhill, and Taylor, 1953, p. 7-11). In determining the thickness at each locality, partings more than three-eighths of an inch thick were omitted, and benches of coal less than 2 feet thick that lie above or below a thicker parting of rock or bone were also omitted. In computing tonnages each acre-foot of coal was assumed to weigh 1,750 tons.

Although several of the beds for which reserves were computed could probably be strip-mined locally, no attempt was made to estimate reserves of stripping coal except on lower Deep Creek, in T. 2 S., R. 14 W. (pl. 17). There the results of subsurface exploration with a bulldozer and power auger indicate that almost 200,000 tons of coal, in a 4-foot bed under less than 25 feet of overburden, occurs in an area of 28 acres between localities 35 and 36.

\section{DESCRIPTION OF COAL BY TOWNSHIPS}

Detailed descriptions of outcrops of potentially valuable coal beds in each township of the Homer district are given on the following pages. Detailed graphic sections of the coal beds in each township appear on the plates indicated under each township heading. For convenience in describing the coal in unsurveyed parts of the district township lines have been projected schematically on plates 17 and 18 to include all areas containing possibly valuable coal.

\section{T. 2 N., R. 12 W.}

\section{Plate 20}

Coaly beds are exposed at localities 1 and 2 but are too thin and dirty to be of value.

At locality 3 (pl. 17) a coal bed exposed in the beach bluff consists of 2 feet of bony coal underlain by an equal thickness of bone. The bed dips $4^{\circ} \mathrm{NE}$. and is exposed for a quarter of a mile, being cut off to the south by erosion at the base of the glacial gravel, and to the north by the inferred fault south of Clam Gulch.

The upper coal bed at locality 5 (T. 1 N., R. 12 W.) was traced to a point about 2,000 feet northeast of the township line and so underlies a small part of T. 2 N., R. $12 \mathrm{~W}$.

\section{T. 1 N., R. 12 W.}

Plate 20

The upper bed at locality 5 (pl. 17) has a total thickness of about 4 feet, of which the upper half is bony. This bed was traced along the beach from the township line to the fault south of locality 5 . About 3 feet below is a bed containing a little less than 2 feet of clean coal.

A double bed exposed at locality 6 may be the same as the one bed at locality 5 but a fault of unknown displacement between the two locali- 
ties precludes positive correlation. The upper bench contains 2.2 feet of partly bony coal. This bed is cut off by glacial deposits about a quarter of a mile south of locality 6 .

A 3-foot coal bed was traced from locality 8 , where it is cut off by glacial gravel, across the mouth of Falls Creek to a point 1,500 feet north of the creek mouth, where it dips below beach level.

The 3-foot coal bed measured at locality 9 , just west of the township line, may be assumed to underlie at least a few hundred acres in the northwestern part of the township.

\section{T. 1 N., R. 18 W.}

Plate 20

A coal bed outlines a very gently folded anticline in the beach bluffs between localities 9 and 12 (pl. 17). This bed is more than 3 feet thick at localities 9 and 11, including some bony coal at the top and base. At locality 10, less than 3 feet of coal is exposed but the top of the bed has been eroded.

A coal bed between 3 and 4 feet thick is exposed at localities 12 and 13. It was traced from the base of the gravel north of locality 12 to the fault south of locality 13 . A higher bed, containing more than 5 feet of coal, was traced from the fault to a point midway between localities 12 and 13, where it is cut off at the base of the gravel.

A double bed containing more than 3.5 feet of coal in 2 benches is exposed near the top of the section at locality 16 . It is cut off at the base of the gravel south of the section locality and dips into the beach about mid way between localities 15 and 16 .

$A$ coal bed that is 3 feet thick at locality 17 and almost 4 feet thick at locality 18 was traced across a barely perceptible anticline between localities 17 and 19. Immediately to the south an overlying bed, which contains at least 3.6 feet of coal at locality 19,1 foot at locality 20 , and 2.5 feet at locality 21 , lies in a broad, shallow syncline.

\section{T. 1 S..., R. 13 W.}

Plate 20

A bed containing 2.5 feet of clean coal is exposed a few feet above the beach at locality 22 (pl. 17). Its gentle easterly dip carries it below the beach a few hundred feet northeast of the section locality and to the base of the gravel about 2,000 feet to the south.

\section{T. 1 s., R. 14 W.}

\section{Plate 20}

A 6-foot coaly zone exposed at locality 26 (pl. 17), and near the base of the section at locality 27 , contains about 2 feet of fairly clean coal in its upper part. A bed 30 feet higher stratigraphically is at least 3.7 feet thick where cut off by glacial gravel at locality 27 , and 2.5 feet 
thick where it dips into the beach at locality 28. Both of these beds are offset several feet by a reverse fault near locality 27 . A bed containing 4.4 feet of coal is exposed below high-tide level at locality 28 .

The next higher coal bed is only 1 foot thick at the base of the gravel at locality 28 but thickens to 4 feet near beach level at locality 29 . Three feet above this bed is a 5.5-foot coaly zone including 2 feet of clean coal at its base.

The section at locality 31 includes 4 coal beds 2 to 4.4 feet thick separated by 1.5 to 6 feet of claystone. These beds are cut off at the base of the gravel between localities 29 and 31 and dip into the beach between localities 31 and 32 .

A bed exposed near beach level at locality 33 , just south of the township line, is at the crest of a very gently folded anticline. This bed, which contains about 4 feet of partly bony coal, extends only a short distance north of the township line before dipping below beach level.

T. 2 S., R. 18 W. (UNSURVEYED)

Plate 21

At locality 37 (pl. 17) a 3-foot coal bed is exposed in the north bank of Deep Creek. A dip of $17^{\circ} \mathrm{NW}$., among the steepest recorded in the Homer district, was measured on this bed.

Coal beds ranging from 2.3 to 4.0 feet in thickness were measured at localities 38 to 43 along Deep Creek. Although exposures are not continuous, an almost flat dip indicates that the measured sections probably are all on the same bed, and this was assumed in computing reserves in this area. The thinner beds at the top of the section at locality 38 and at the base of the section at locality 42 possibly are splits of the main bed.

The beds at localities 45 to 49 , containing 2 to 5 feet of coal, probably represent, in ascending order, a rather closely spaced series of beds dipping gently southeastward.

The bed at locality 50 , which is too thin to be of value, and the 5-foot bed at locality 51, of which only the lower half is of minable quality, are on opposite limbs of a relatively tightly folded syncline, but their stratigraphic relation is unknown.

The 3 coal beds at locality 52, containing 2 to 4 feet of coal, are apparently across a northeastward-trending anticlinal axis from the bed at locality 51 and not far from it stratigraphically.

Two coaly beds measured at locality 53 are too thin and dirty to be of value.

$$
\text { T. 2 S., R. } 14 \text { w. }
$$

Plates 21 and 22

The 4-foot bed at locality 33, described in T. 1 S., R. 14 W., extends only a short distance southwestward before dipping into the beach. 
At locality 34 (pl. 17) a 5-foot coal bed, of which the lower 3 feet includes several partings and the roof is eroded, is exposed in the south bank of Deep Creek just above the highway bridge. This bed probably is the same as the 4-foot bed at locality 35 , to which it was traced intermittently along the face of the bluff south of Deep Creek. The 4-foot bed is also exposed in the north edge of a low terrace in the $\mathrm{SE} 1 / 4$ sec. 3, and forms ledges in the bed of Deep Creek in the NW1/4 sec. 11.

A special study of this area was made in 1954 with a bulldozer and power-auger unit to determine whether some of this coal might be minable by stripping. To test this possibility several trenches were opened, and 11 holes were were drilled. The locations of the trenches and the drill holes and logs of the drill holes are shown on plate 28. The finding of gravel instead of coal in drill hole 2 and in the trenches west of drill hole 1 indicated that stream erosion had probably removed the coal from most of the flood-plain area. Operations were therefore shifted to the low terrace to the west, where a series of trenches and drill holes along its north edge confirmed the presence of an essentially horizontal 4-foot coal bed under about 10 feet of overburden (pl. 28, section $A-A^{\prime}$ ). The approximate boundary of the area underlain by the 4-foot coal bed with a maximum of 25 feet of overburden is shown on plate 28 . The southern boundary was chosen more or less arbitrarily on the assumption that the coal bed extended southward without change in altitude. The outlined tract is about 28 acres in area and, assuming an average thickness of 4 feet and a weight of 1,750 tons per acre-foot, contains 196,000 tons of coal. Although swampy conditions restricted the subsurface work to the northern part of the terrace, the topography and horizontal bedding suggest that the coal may lie at shallow depth for some distance south of the area mapped.

Farther up Deep Creek, at locality 36, a horizontal coal bed exposed in the east creek bank contains at least 5.8 feet of coal in 2 benches separated by a 6 -inch parting. The bed is immediately overlain by glacial gravel, so an unknown thickness has been removed by erosion.

A 5-foot bed consisting mainly of bony coal was traced for half a mile along the beach bluff from the base of the gravel south of locality 55 to a point north of locality 54 where it dips into the beach. At locality 55 a second bed containing about 3 feet of coal is exposed about 35 feet lower in the section.

A 3 -foot bed is exposed about 40 feet above the beach at locality 56 but descends gently northward. A thin bed of bony coal lies about 30 feet lower in the section.

A bed containing more than 5 feet of coal was traced from beach level at locality 57 to the base of the gravel at locality 58. A bed 
50 feet lower in the section is less than 2 feet thick at the base of the section at locality 58 but thickens to more than 4 feet at locality 59 .

A 4.5-foot coal bed at the base of the bluff at locality 59 was traced with little change in thickness to locality 60 . Although concealed to the south it presumably continues several hundred feet farther before being cut off at the bedrock surface.

A bed containing 2.5 feet of coal is exposed near beach level at locality 60 , but thins to less than 2 feet at a point 800 feet to the south.

The coal beds exposed at localities 61,62 , and 63 are all less than 2 feet thick.

A 3-foot coal bed was traced for about 1,000 feet from beach level a short distance north of locality 64 to the base of the glacial gravel a few hundred feet south of the township line.

\section{T. 3 S., R. 10 W. (UNSURVEYFD)}

Plate 27

The only coal of possible economic value mapped within the theoretical boundaries of this unsurveyed township is exposed at locality 177 (pl. 18), at the head of a small west tributary of the Fox River. Although 5 coaly zones are exposed at this locality, in only 2 of them is the coal thick or pure enough to be of possible value. The lowest bed in the section contains 2.7 feet of coal with 3 thin partings, and a bed 70 feet higher contains 2 feet of clean coal.

Although strata of the Kenai formation are exposed for several miles farther northeast along the west side of the valley of the Fox River, they contain only a few scattered coal beds too thin to be of value.

\section{T. 3 S., R. 14 W.}

Plate 22

Although several coaly zones are exposed in the beach bluff at locality 65 (pl. 17), only 1 bed, about 40 feet above the beach, is thick enough to be of value. This bed is 6 feet in total thickness, but only the lower part, including 2.4 feet of partly bony coal, probably would be considered minable.

The only coal at locality 66 is in 3 beds each less than 2 feet thick.

At locality 67 a 3.3-foot seam with a 7 -inch parting is exposed 25 feet above the beach. At the mouth of Happy Creek this bed is upthrown about 6 feet on the north side of a fault, north of which it dips into the beach.

From locality 68 a 3.4-foot bed about 30 feet lower in the section rises gently southward to the top of the section at locality 69 , after being upthrown about 8 feet on the south side of a fault just south of locality 68.

A 4.5-foot coal bed was traced between localities 69 and 70 and apparently continues about 1,000 feet further southward before being 
cut off at the base of the gravel. About 20 feet lower in the section a 3.5-foot bed, including 1 thin parting, was traced 1,000 feet southward from locality 70.

At locality 71 a bed containing 2.8 feet of coal is exposed about 30 feet above the beach.

\section{T. 4 8., R. 10 W. (UNSURVEYED)}

Plate 27

Locality 171 (pl. 18) is near the head of Moose Creek canyon on the north wall. In an incompletely exposed section of 530 feet (pl. 19), 6 coal beds were measured, of which only 3 are of possible value and none could be correlated with beds to the west. The lowest bed in the section contains at least 2.5 feet of clean coal, the roof being concealed. About 90 feet higher is a 6-foot seam with several thin partings. A 5.5-foot bed containing more than 4 feet of coal with 3 thin partings is about 100 feet below the top of the exposed section.

At localities 172 and 173 , on the north walls of west tributary canyons of Fox Creek (pl. 18), several coal beds of minable thickness are scattered through 800 to 900 feet of strata (pl. 19). As the dip is only $5^{\circ} \mathrm{N}$., and the sections are at about the same altitude and only half a mile apart, all but the upper 90 feet of strata at locality 173 should be represented at locality 172 ; however, no similarities in the 2 sections were found to suggest possible correlations, thus illustrating the extreme lenticularity that characterizes the beds of the Kenai formation. The section at locality 172 includes 5 coal beds 2.5 to 4 feet thick, and the section at locality 173,9 beds 2 to 4.5 feet thick.

At locality 174 a slide scar on the west side of Fox Creek exposes a 5-foot seam with 1 thin parting, underlain by several thin beds. At locality 175 , four coal beds containing 2.5 to 4.8 feet of clean coal are exposed in a small tributary canyon.

At locality 176, five beds ranging from 2 to 5 feet in thickness are exposed in the face of a steep bluff.

\section{T. 4 S., R. 11 W. (UNSURVEYED)}

Plates 26 and 27

Several coal beds, including beds $J$ to $M$, are exposed in bluffs and canyons along the northwest shore of Kachemak Bay between localities 162 and 167 (pl. 18). Beds $H$ and $I$ are exposed near the base of the section at locality 162 but are too thin to be of value.

Bed $J$ at locality 162 consists of an upper 1.5 -foot bench of clean coal separated by about 10 feet of siltstone and claystone from a partly concealed lower bench containing at least 2 feet of bony coal. The lower bench of bed $J$ is probably represented at locality 163 by a partly concealed bed containing at least 2 feet of coal. This 
and overlying beds are upthrown about 20 feet on the northeast side of an almost vertical fault between localities 162 and 163 .

Bed $K$ contains at least 2 feet of clean coal at locality 163 where only the lower part is exposed, but it thins to less than 2 feet in total thickness at locality 164 . Bed $K$ was tentatively correlated with a 5-foot bed containing about a foot of partings at locality 162, with a 4.7-foot bed at locality 165 , and with a 7 -foot bed containing several partings at locality 166.

Bed $L$ is a double bed, with a 1- to 4-foot parting, that was traced with reasonable certainty between localities 162 and 167 . The upper bench is 2.5 feet thick at locality 162 , at least 2.5 feet thick at locality 163 where the roof is concealed, has been burned at locality 164, and is 3.6 feet thick at locality 167 . Elsewhere both benches are less than 2 feet thick and therefore considered valueless, except at locality 166 where, because of a thin parting, both benches could be mined as a single bed containing more than 3 feet of coal.

A bed about 25 feet above bed $L$ contains more than 4 feet of coal in 2 benches at locality 167 , but it thins southwestward to less than 2 feet at locality 166.

Bed $M$ was identified at localities $163,165,166$, and 167 , where its thickness ranges from 4.6 to at least 5.2 feet. The roof was concealed at localities 163 and 166, and the entire bed was covered at locality 164. It is marked by a burned zone at locality 162 and a short distance to the southwest is cut off at the base of the glacial gravels.

A coal bed a little more than 2 feet thick lies 80 to 95 feet above bed $M$ at localities 166 and 167 . This bed is overlain by a 2.3 -foot coal bed at locality 166 and underlain by a 2 -foot bed at locality 167.

The beds exposed at localities 168 to 170 , in the walls of Swift Creek canyon, are stratigraphically above the beds exposed to the south along Kachemak Bay. The stratigraphic distance between bed $M$ near the top of the section at locality 167 , and bed $N$, near the base of the section at locality 170 , could not be determined accurately but probably is at least 200 feet.

Bed $N$ contains 3.6 feet of clean coal at locality 170. It was tentatively correlated with a 7 -foot coaly zone near the base of the section at locality 169 which includes 2.1 feet of clean coal at its base.

Bed $O$ includes only 2.5 feet of coal of minable thickness at locality 168 but at least 5.3 feet at locality 169 , where the base of the bed is concealed. The probable position of bed $O$ at locality 170 is marked by a burned zone.

Bed $P$ is 2.7 feet thick at locality 168, at least 3.2 feet at locality 169 , and 4 feet at locality 170 .

Bed $Q$ is a double bed in which the upper bench is 6 feet thick, including 2 thin partings, at locality 168, at least 6.3 feet at locality 
169 , and 7 feet at locality 170 . The lower bench, below 2 to 8 feet of claystone, is about 2 feet thick at all 3 localities.

Bed $R$ was identified only at locality 168 , where it contains nearly 4 feet of clean coal.

Bed $S$ consists of 4.4 feet of clean coal at locality 168 , but at locality 169 it is 8.5 feet thick, including 1.2 feet of claystone in 5 partings. Bed $S$ is not exposed at locality 170 , as it is stratigraphically higher than the top of the section.

Bed $T$ at locality 169 contains at least 3.2 feet of coal in 2 benches separated by a 5 -inch parting. It was tentatively correlated with a 3 -foot bed with 2 thin partings at locality 168 .

Bed $U$ contains 5.8 feet of clean coal at locality 169 . It apparently thins abruptly northwestward, as its expected position at locality 168 is marked by 3 thin coaly beds. Two 2 -foot coal seams are exposed higher in the section at locality 168 , the lower one of which is also exposed at locality 169 .

None of the beds exposed on Swift Creek were recognized farther east.

\section{T. 4 S., R. 15 W.}

Plate 22

The only coal exposures in this township are at localities 72, 73, and 74, where a thin double bed was traced along the beach bluffs for about half a mile. At locality 72 it contains 3.5 feet of coal in a total thickness of 4.5 feet. At locality 73 the lower bench contains about 2 feet of coal and the upper bench about 1 foot, separated by 1.4 feet of claystone. At locality 74 the upper bench has been eroded away and the lower bench contains less than 2 feet of coal.

\section{T. 5 8., R. 11 w. \\ Plates 25 and 26}

Bed $D$ is about 40 feet above the beach at locality 148 (pl. 18), where it is 3.5 feet thick, including 2 thin partings, but drops to beach level near locality 149, partly as a result of dip and partly as a result of faulting that dropped it 13 feet on the northeast side. At locality $149,3.2$ feet of coal is exposed, but both the roof and floor are concealed.

Bed $E$ was traced with few interruptions from locality 148 , between McNeil and Cottonwood Creeks, to locality 159, west of Falls Creek. In this interval, bed $\mathrm{E}$ and all overlying beds are cut by a series of steep to vertical faults (see section on plate 18). At locality 148 bed $E$ contains almost 5 feet of clean coal, but at locality 149 it is represented by a 6-foot coaly zone with no coal of minable thickness, unless the partly concealed upper bench is more than 2 feet thick. At locality 150 an upper bench contains 2.1 feet of clean 
coal, but northeastward as far as locality 151 the entire bed is too thin to be of value. At localities 152 to 156 bed $E$ contains 2 to 3 feet of coal, but at locality 157 it is split into several thin benches of no value. The partly exposed upper bench shows 1.6 feet of coal at locality 159 , northeast of which it dips into the beach.

Bed $F$ is less than 2 feet thick at localities 148 to 151 but contains 2 feet or more of coal at localities 152 and 153 . It is burned at locality 154 and thin at locality 155 , but at localities 156 and 157 the upper of 2 benches contains about 2.5 feet of coal. Bed $F^{\prime}$ was traced to the mouth of Falls Creek but nowhere northeast of locality 157 is it of minable thickness.

Bed $G$ contains 2.2 feet of coal at locality 159 but thins to less than 2 feet in both directions.

Beds $H$ and $I$ and an underlying bed each contain about 2 feet of coal at locality 161 , but they all thin northeastward; however, bed $I$ is possibly represented by a double bed at locality 160 on Falls Creek containing 2.4 feet of coal in the lower bench. None of these beds was identified in the beach bluffs southwest of locality 161 .

Several coal beds 2 feet or more in thickness are exposed above bed $F$ in the steep bluffs between McNeil and Falls Creeks, but they are accessible at only a few places and none of them could be followed along the outcrop to check their correlation. These include a 2-foot bed and a 2.5-foot bed at localities 149 and 150, a 2.5-foot bed at localities 152 and 153, a 2-foot bed and a 3 -foot bed at locality 156, and 5 beds ranging from 2 to 5 feet in thickness at locality 157. One of the beds at locality 157 may be correlative with bed $J$, which could not be traced southwest of locality 158.

Bed $J$ is probably represented at locality 158 by a bed containing 4.2 feet of coal. At locality 159 bed $J$ contains 2.5 feet of clean coal. A bed tentatively identified as $J$ at locality 160 on Falls Creek has 2 benches 1.5 feet apart containing 2.3 and 3.3 feet of partly bony coal. At locality 161 the upper bench of bed $J$ is less than 2 feet thick but the lower bench contains 2.9 feet of clean coal.

Bed $K$ was tentatively identified at locality 160 as a bed containing 3.4 feet of partly bony coal. At locality 161 it is 4.7 feet thick, including a 6 -inch parting.

Bed $L$ and an overlying bed are present at locality 161 but their outcrops are burned.

\section{T. 6 S., R. 12 W.}

\section{Plates 24 and 25}

At locality 133 (pl. 18) at least a dozen coal beds are exposed in a short canyon that indents the Homer escarpment, but only 3 of them contain as much as 2 feet of coal. A 2.7-foot bed lies near the middle of the measured section, and beds containing 2 and 2.2 feet of coal are 
exposed near the top. All these beds are thin or absent at locality 134 , in the next canyon to the northeast.

Many thin coal beds are present in the section at locality 134, but only 2 near the base of the section, containing 2.7 and 3.2 feet of coal, are thick enough to be of possible value. The probable continuations of these 2 beds at locality 133 are thin and worthless.

At locality 135, on Fritz Creek about half a mile north of the road crossing, a bed at least 2.6 feet thick is partly exposed in a small strip pit.

At locality 138 a bed containing at least 2.6 feet of coal is exposed near the top of the beach bluff. Northeast of the section locality the bed is upthrown about 50 feet on the northeast side of a vertical fault, beyond which it was traced down the component dip to the base of the section at locality 139 , where it is 2.7 feet thick.

Bed $A$, with an average thickness of about 3 feet, was traced from the top of the section at locality 140 along the beach bluff to the base of the section at locality 142 . It is upthrown 10 feet on the northeast side of a fault near locality 141. A 2 -foot coal bed lies about 140 feet below bed $A$ at locality 140 .

Bed $B$, known as the Curtis seam during early mining operations, is at least 3.6 feet thick at the top of the section at locality 142, where the roof is concealed, and at least 5 feet thick at beach level at locality 143 , where the floor is concealed. West of locality 143 the coal is downthrown 36 feet on the northeast side of a vertical fault. Just west of the fault are traces of two short tunnels driven on this bed by early-day miners, and east of the fault the coal has been burned almost to locality 143 .

Bed $C$ at locality 143 is about 100 feet above the beach and nearly 4 feet thick, with a thin parting near its center. At locality 144 east of McNeil Creek its position is marked by a burned zone, but at localities 145 and 146 it appears near the beach as a 5 -foot bed, including 3 coaly shale partings 1 to 5 inches thick.

Bed $D$ was traced from an altitude of about 150 feet at locality 143 to beach level at locality 147 with a thickness ranging from 3 to 4 feet. Beds $C$ and $D$ have been burned at locality 144 . Northeast of locality 147 bed $D$ is upthrown almost 80 feet on the northeast side of a southwestward-dipping fault, beyond which it continues across the township line to locality 149 before disappearing below beach level.

Bed $E$ is not present west of McNeil Creek but appears about half way up the bluffs at localities 144,146 , and 147 , where coal thicknesses of 3.6,3.5 and 4.8 feet were measured. Bed $E$ is also upthrown on the northeast side of the fault near the township line.

A bed that lies 40 to 60 feet above bed $E$ at localities 144, 146, and 
147 may be the same as bed $F$ farther northeast. It is a double bed with a thin and dirty lower bench and an upper bench containing 2 to 2.5 feet of clean coal.

At locality 144 three beds more than 2 feet thick overlie bed $F(?)$. The 2.5-foot bed at the top of the sections at localities 146 and 147 is possibly correlative with the middle bed of the three above bed $F($ ?) at locality 144 (pl. 25).

\section{T. 5 S., R. 18 w.}

Plate 24

At locality 119 (pl. 18), on the northwest bank of the Anchor River, a partly concealed bed contains at least 2.6 feet of bony coal.

The 3.9-foot coal bed at locality 92 in the adjoining township has a northeast dip and extends into the southwest corner of T. 5 S., R. 13 W.

At locality 120, on the southeast slope of Ohlson Mountain, a nearly horizontal bed partly exposed in a small gully contains at least 2.7 feet of coal.

At locality 121 a partly exposed bed near the head of a minor tributary of Fritz Creek contains at least 2 feet of coal and bony coal.

At locality 130 a 2.4 -foot bed of clean coal is exposed at the base of the exposed section in Waterman Canyon. About 80 feet higher in the section is a 2.7-foot coal bed that is probably correlative with a 2 -foot bed at the base of the section at locality 129 , in the next canyon to the southwest.

The Woodman bed was originally identified near the head of Bear Canyon, at locality 126 in T. 6 S., R. 13 W. It is probably represented at localities 129 and 130 by a bed containing 2.7 to 3.0 feet of clean coal.

A 3.5-foot coal bed 33 feet below the Fletcher bed at locality 129 was tentatively correlated with a 2.3 -foot bed 37 feet below the Fletcher at locality 130.

The Fletcher bed, originally identified as the top coal bed at locality 127 , is probably represented at localities 129 and 130 by beds 2.4 and 3.0 feet thick. Two overlying beds at these localities contain less than 2 feet of coal.

At locality 131 at the head of Waterman Canyon, some strip mining has been done on a 7 -foot coal bed that contains several bony partings and lenses.

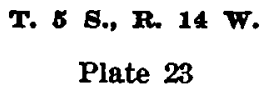

Plate 23

At locality 91 (pl. 18), on the southeast bank of the Anchor River, 5.5 feet of partly bony coal immediately underlies glacial gravel. The bedding of the coal is horizontal. 
At locality 92 a 3.9 -foot coal bed is exposed in a shallow gully. As the dip is northeast this bed underlies only a small area in the southeast corner of the township.

T. 5 S., R. 15 W.

Plate 22

The only known coal beds of possible value in this township are exposed in the beach bluffs southeast of Troublesome Creek. Two beds, each containing about 2 feet of coal, are exposed at locality 75 (pl. 18). About a quarter of a mile to the southeast both beds are cut by a zone of faulting near the crest of an anticlinal fold, beyond which they were traced to localities 76 and 77. The upper bed, containing 2.5 to 3.5 feet of coal, is exposed about 50 feet above the beach at locality 76 and at beach level at locality 77 . The lower bed is less than 2 feet thick at locality 76 but contains at least 2 feet of coal with a few thin partings at locality 77 , where it crops out about 20 feet below high-tide level.

At locality 78, a 3.8-foot coal bed, including a 6 -inch parting, appears beneath the glacial gravel, and a 3 -foot coal bed with a few thin partings is exposed near beach level. In addition, 3 coal beds 2 to 3 feet thick, probably including the 2 at locality 77, are exposed well below high-tide level.

A bed containing at least 3.7 feet of coal with a few thin partings is partly exposed beneath the gravel at locality 79 and is fully exposed about 15 feet above the beach at locality 80 . At locality 79, 2 coal beds more than 2 feet thick, one of which may be the bed exposed near beach level at locality 78, are exposed below high-tide level.

A multiple bed containing about 3.5 feet of coal, in 3 benches separated by 2 - to 6 -inch partings, crops out just below the gravel at locality 80 , about 15 feet above the beach at locality 81 , and at the base of the gravel at locality 82 .

\section{T. 6 S., R. 12 w. \\ Plate 25}

The only coal of possible value found in this fractional township is at locality 136 (pl. 18), west of the mouth of Fritz Creek, where about 2 feet of coal is exposed in the low beach bluff. It splits and thins to a worthless bed a short distance east of Fritz Creek. The 2 coal beds measured at locality 137 are too thin and dirty to be of value.

T. 6 S., R. 13 W.

Plate 24

The 3.9-foot coal bed described at locality 92 , in T. 5 S., R. 14 W., probably underlies a small area in the northwest corner of this town- 
ship. It may be represented by 1 of 2 thin beds exposed in a gully in the $\mathrm{W} 1 / 2$ sec. 5 .

Many coal beds are exposed in the bottoms and walls of the short canyons and gullies that indent the Homer escarpment, but because of marked lateral changes, lack of recognizable key beds, and complete masking of the beds on the intervening slopes, very few could be correlated from canyon to canyon. Therefore most of the outcrops, except those that could be correlated between two or more canyons, are described by localities rather than by beds in the following paragraphs.

The section at locality 122 includes 5 beds containing 2 feet or more of coal, only 1 of which is completely exposed. This bed contains 3 feet of coal in 3 benches separated by 2- to 4-inch partings. The top bed at this locality is the Cabin bed, of which only the lower 2 feet, consisting of bony coal, is exposed. This bed is 6 feet thick at locality 117, about a mile to the west, and contains 5 feet of coal with an 8 -inch parting at locality 123 , less than half a mile to the east.

The section at locality 123 contains 6 coal beds of possible value in a total thickness of 370 feet. These include, in addition to the Cabin bed, a partly exposed bed containing 3.2 feet of coal divided by a 12-inch parting, 2 partly concealed beds at least 7 feet and 4.5 feet thick separated by 4.6 feet of rock, and 2 beds about 2 feet thick.

At locality 124 the section includes 2 partly concealed beds containing at least 2.5 and 3.6 feet of coal and a higher 3-foot bed. The beds at this locality are upthrown about 50 feet on the northeast side of a northwestward-trending fault.

At locality 125, in a shallow gully near the "east hill road," 3 feet of coal was measured in a partly concealed bed.

At locality 126, in Bear Canyon, 8 coal beds containing 2 feet or more of coal were measured in about 760 feet of strata. The 5 lower coal beds in this section, ranging from 2 to 5 feet in thickness, were not recognized farther northeast. The second coal bed below the Woodman, although only 2 feet thick at this locality, is believed to be the same as the lowest of 3 closely spaced beds at the bottom of the section at locality 127 that contain, in descending order, 1.8, 2.9, and 3.0 feet of coal. The first coal bed below the Woodman is 2.7 feet thick at locality 126, 2.4 feet at locality 127 , but only 1.6 feet at locality 128. The Woodman bed is at least 3 feet thick at locality 126, 2.7 feet at locality 127 , and 2.5 feet, including 2 thin partings and some bony coal, at locality 128 .

The 3-foot coal bed with 2 thin partings 57 feet below the Fletcher bed at locality 128 probably is the same as the 3.5-foot bed 33 feet below the Fletcher at locality 129. This bed is not present at locality 
127, where its place in the section is occupied by a thick sandstone bed.

The Fletcher bed, 2.5 feet thick near the top of the section at locality 127 , thins to 2.2 feet at locality 128 . It could not be traced southwestward with any assurance, but may be represented in Bear Canyon by the partly concealed bed showing 1.7 feet of coal at the top of the section at locality 126 , which is about the same distance above the Woodman.

At locality 128 a double bed 167 feet above the Fletcher contains about 3 feet of coal in 2 benches separated by less than a foot of coaly shale.

The beds just east of locality 127 are upthrown about 40 feet on the northeast side of a northwestward-trending fault.

At locality 132, on the beach 1 mile south of Millers Landing, a section exposed in the beach bluffs includes 6 beds containing 2 to 5 feet of coal. These beds dip gently northward, and those at the northern part of the section are cut by a northwestward-trending fault in which the northeast side was upthrown about 10 feet.

\section{T. 6 S., R. 14 W.}

\section{Plates 22 and 23}

At locality 85 (pl. 18) the section in the beach bluff includes a 2.4foot coal bed near the beach, a closely overlying 4.6 -foot bed, and a 2.5-foot bed with eroded roof beneath the gravel, as well as 2 thin dirty beds. The top bed at locality 85 was traced to a 3.5 -foot bed with a 4-inch parting 15 feet above the beach at locality 86 . The section at locality 86 also includes beds with about 4 and 3 feet of coal 75 and 100 feet above the beach.

The section at locality 87 includes a 2 -foot bed of partly bony coal and 2 thinner beds.

At locality 88 a 4.2 -foot coal bed lies 175 feet above the beach. A bed about 40 feet higher, containing 3.4 feet of coal in 2 benches, was traced to a 4.5 -foot bed at locality 89 , east of which it splits into 2 beds 1.3 and 2.2 feet thick separated by 3 feet of claystone at locality 90. This same bed was visible in an inaccessible cliff west of locality 88 , where it was estimated to be about 5 feet thick.

At locality 89 a bed about 300 feet above the beach contains more than 5 feet of coal in 2 benches separated by 1.6 feet of claystone. 'The bed was traced at about the same level to locality 90 , where it contains at least 5.2 feet of coal with 1 thin parting, the roof being concealed.

At locality 107, the westernmost measured exposure of the Cooper bed lies about 500 feet above the beach on the south face of Bluff 
Point. A bed containing 3.8 feet of coal is exposed more than 200 feet above the Cooper.

The Cooper bed was traced almost continuously along the face of the bluffs back of the big landslide area between localities 107 and 115 , and along the beach cliffs from locality 115 to the Homer Coal Corp. mine near the east township boundary. The thickness and character of the Cooper bed throughout this distance of more than 3 miles are shown by the detailed sections on plate 23 .

At locality 117, six coal beds ranging from 2 to 6 feet in thickness, as well as many thinner beds, are distributed through about 900 feet of strata. Of these, beds 1 to 5 are exposed in the beach bluffs, and the higher beds, including the 6-foot Cabin bed, are exposed in the led of Bidarki Creek.

The Lofgren bed underlies a broad, flat-topped ridge in the northeast corner of the township. Its outcrop was traced along the north side of the ridge between localities 93 and 100, and around the west and south sides between localities 93 and 106, where it has a general dip of about $5^{\circ} \mathrm{NE}$. The bed shows marked changes in both character and thickness from place to place (pl. 23), ranging from a single bed containing 2 to 2.5 feet of coal to a multiple bed 6 feet or more in thickness including several coaly shale partings. At several localities the full thickness of the bed is not exposed, but the average coal content appears to be about 3.5 feet.

The 2 -foot bed at locality 103 probably closely overlies the gently northeastward-dipping Lofgren bed.

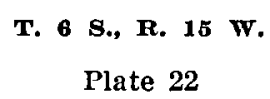

At locality 83 (pl. 18) 4 feet of coal in a partly eroded bed is exposed beneath the gravel 25 feet above the beach. This bed was tentatively correlated with similar beds at localities 82 and 84 , but as it is largely eroded at intermediate points it probably underlies a very small area in the township.

\section{REFERENCES CITED}

Atwood, W. W., 1909, Mineral resources of southwestern Alaska : U.S. Geol. Survey Bull. 379, p. 108-152.

Averitt, Paul, Berryhill, L. R., and Taylor, D. A., 1953, Coal resources of the United States : U.S. Geol. Surv. Circ. 293.

Barnes, F. F., 1951, Preliminary report on coal deposits near Homer, Alaska : U.S. Geol. Surrey Bull. 963-E, p. 203-208.

Capps, S. R., 1940, Geology of the Alaska Railroad region: U.S. Geol. Survey Bull. 907.

Dall, W. H., 1896, Report on coat and lignite of Alaska : U.S. Geol. Survey 17th Ann. Rept., pt. 1, p. 763-906. 
Dall, W. H., and Harris, G. D., 1892, Correlation papers-Neocene : U.S. Geol. Survey Bull. 84, p. 237-238.

Karlstrom, T. N. V., 1955, Kenai lowland, in Hopkins, D. M., and Karlstrom, T. N. V., Permafrost and ground water in Alaska: U.S. Geol. Survey Prof. Paper 264-F, p. 133-134.

Kirsopp, John, Jr., 1903, Coal fields of Cook Inlet, Alaska, U.S.A., and the Pacific coast : Inst. Min. Eng. (England), Trans., v. 21, p. 536-559.

Krinsley, D. B.. 1953, Southwest Kenai Peninsula, Alaska, in Péwé, T. L., and others, Multiple glaciation in Alaska : U.S. Geol. Survey Circ. 289, p. 5-6.

Martin, G. C., 1915, The western part of Kenai Peninsula : U.S. Geol. Survey Bull. 587, p. 41-112.

Smith, P. S., 1939, Areal geology of Alaska: U.S. Geol, Survey Prof. Paper 192.

Stone, R. W., 1906, Coal flelds of the Kachemak Bay region: U.S. Geol. Survey Bull. 277, p. 53-73.

United States Weather Bureau, 1955, Climatological data, Alaska annual summary 1954. 


\section{INDEX}

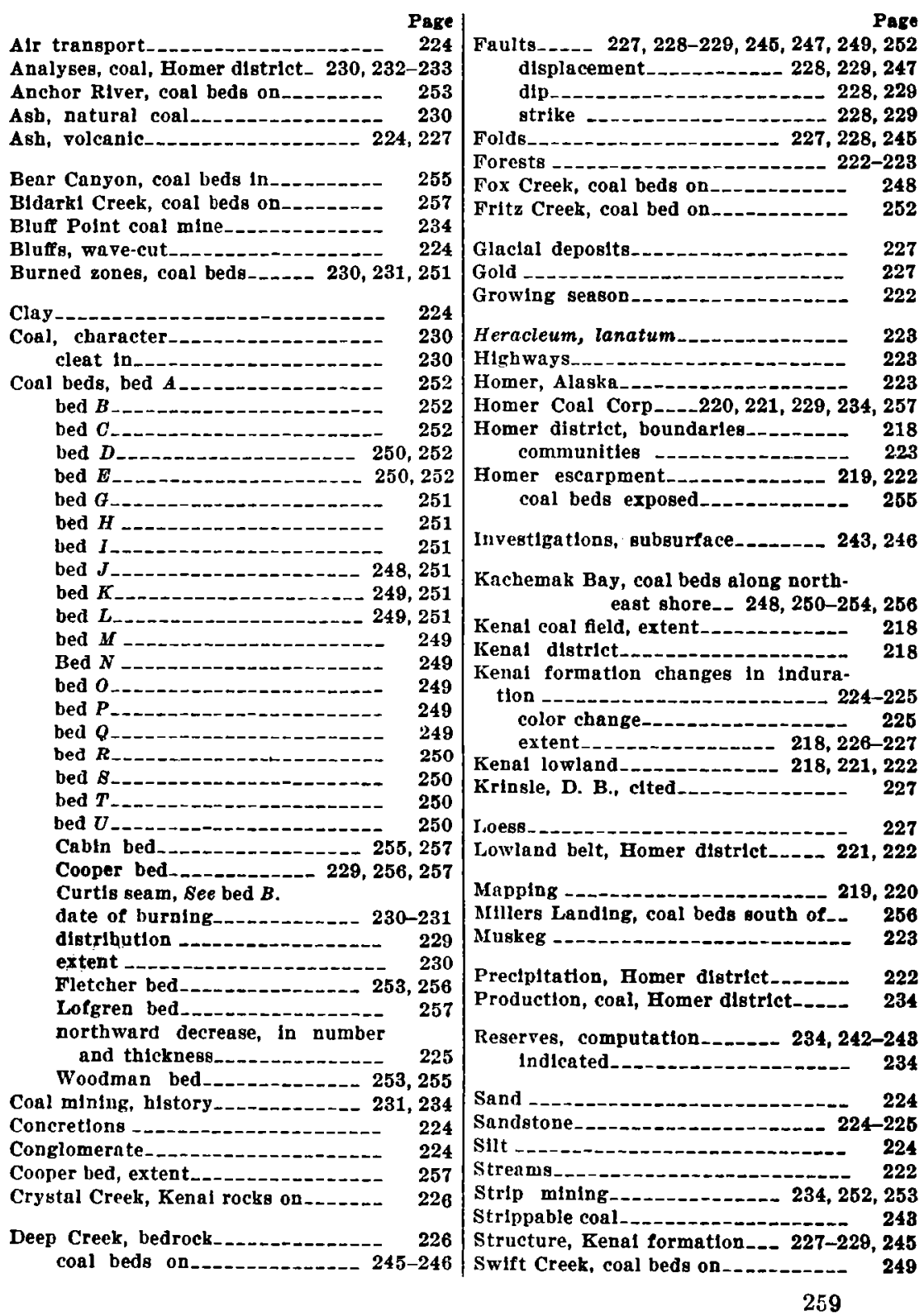




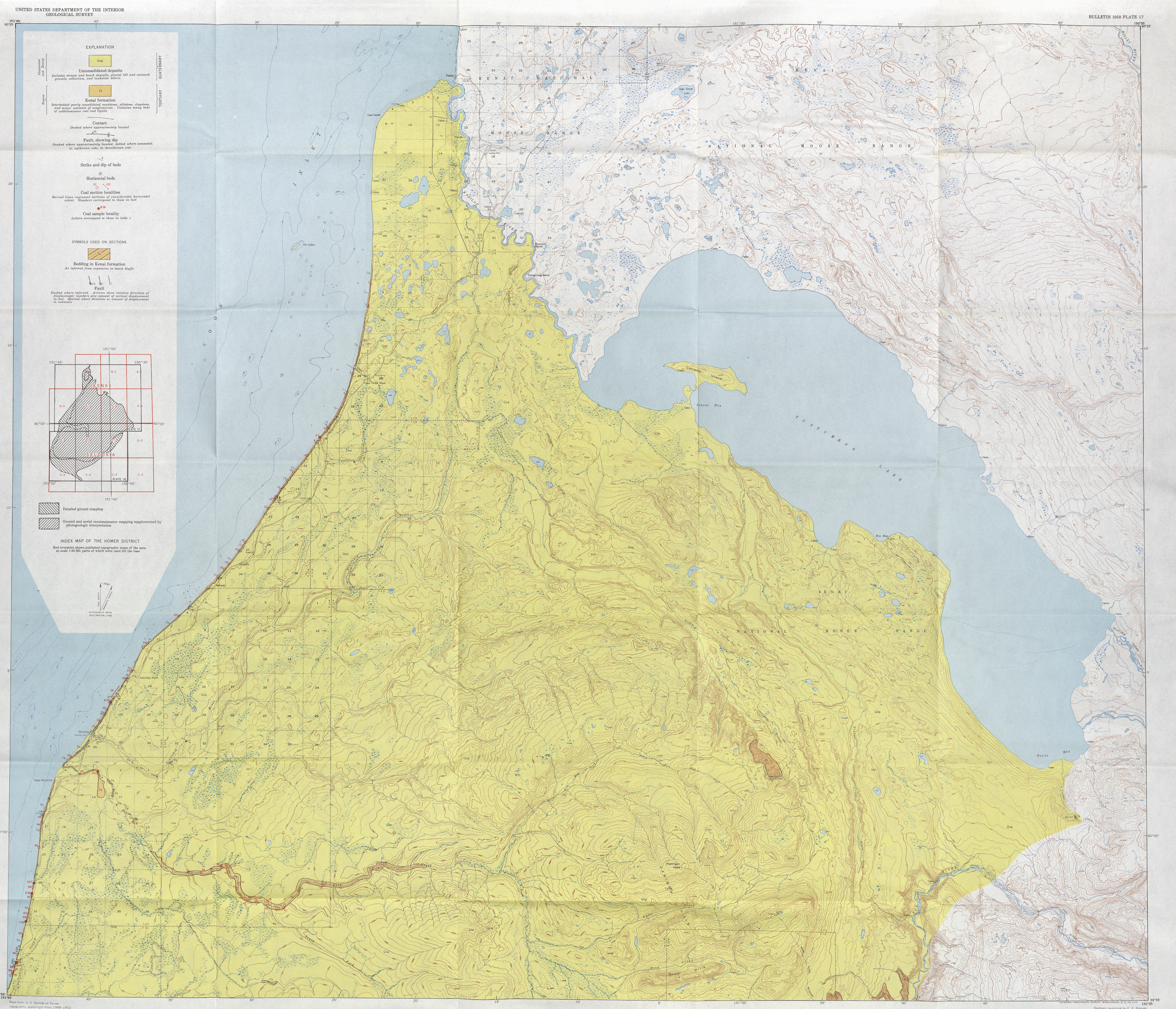

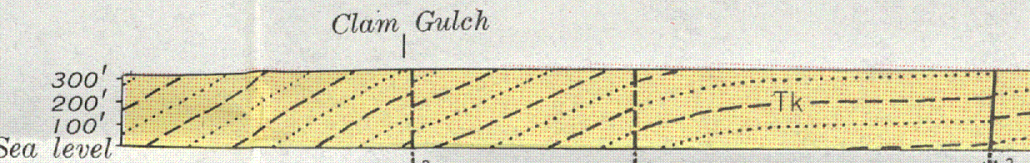





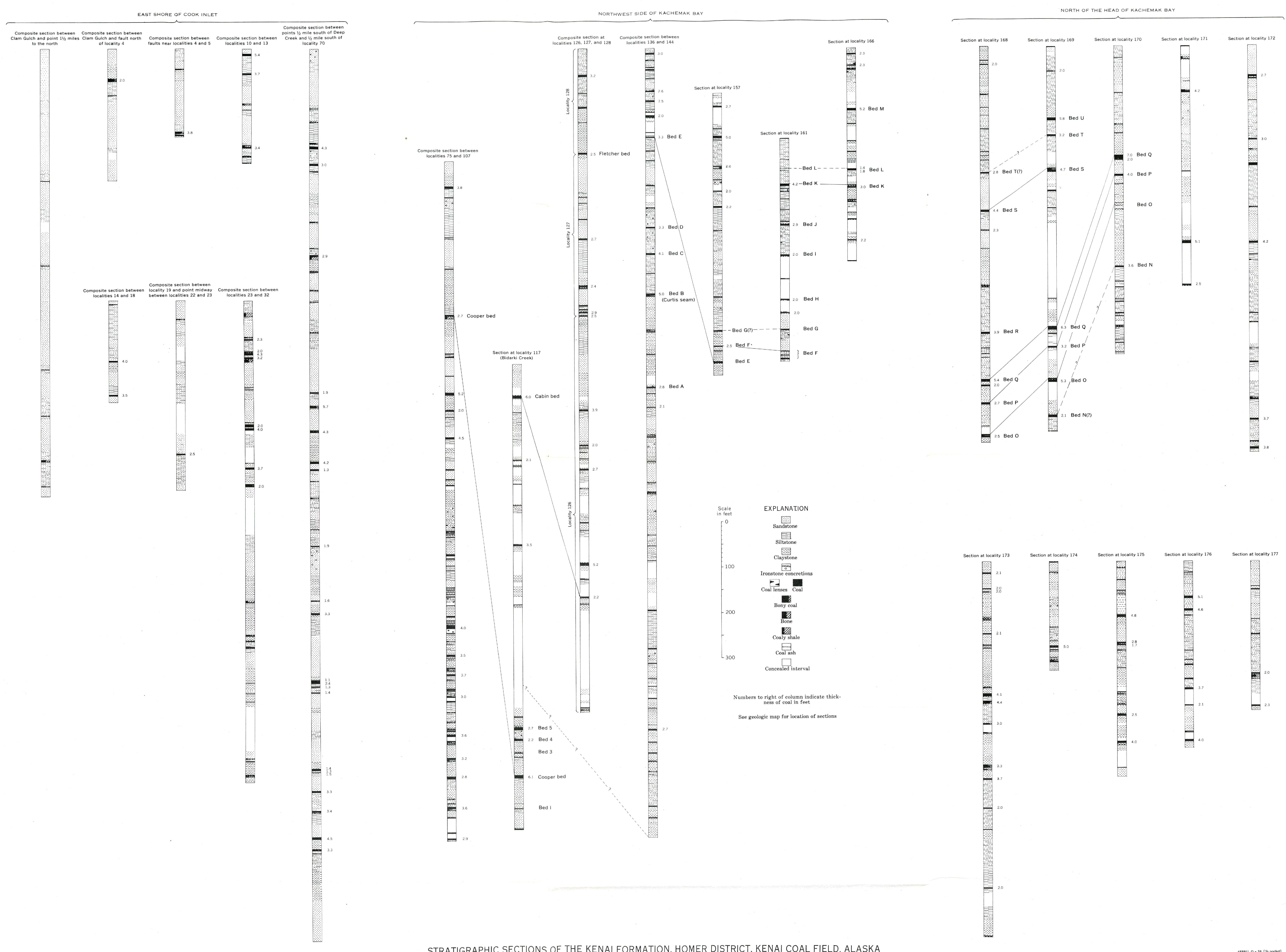


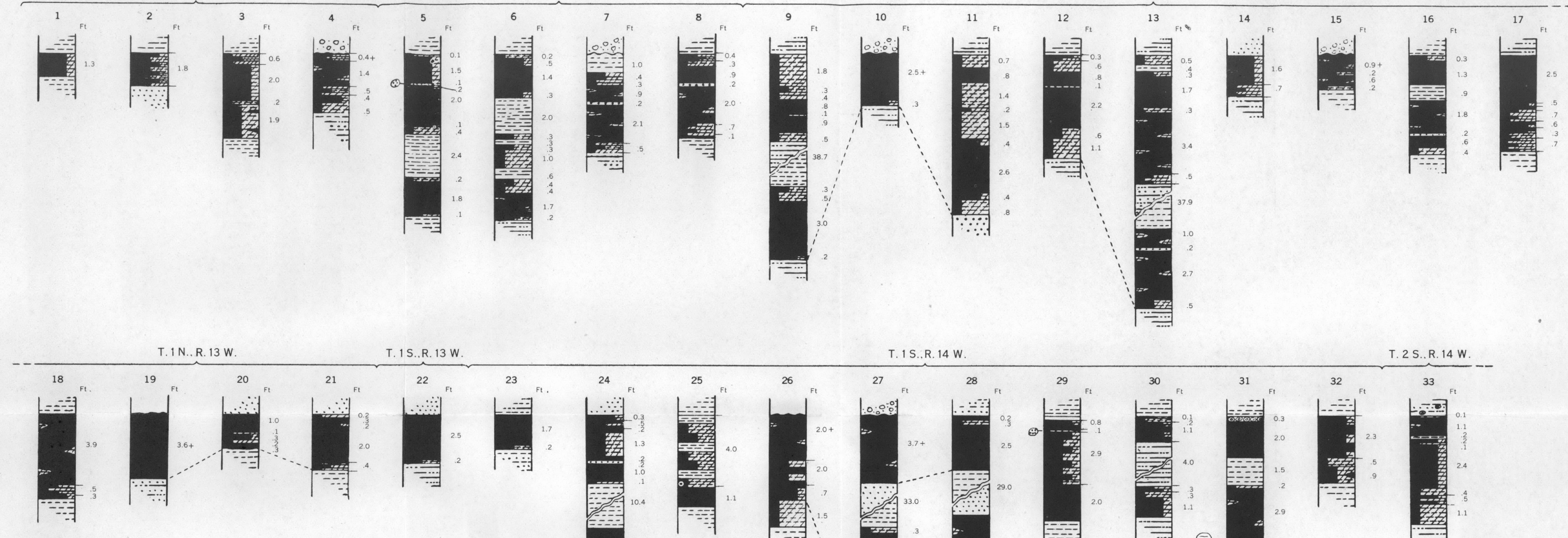

EXPLANATION
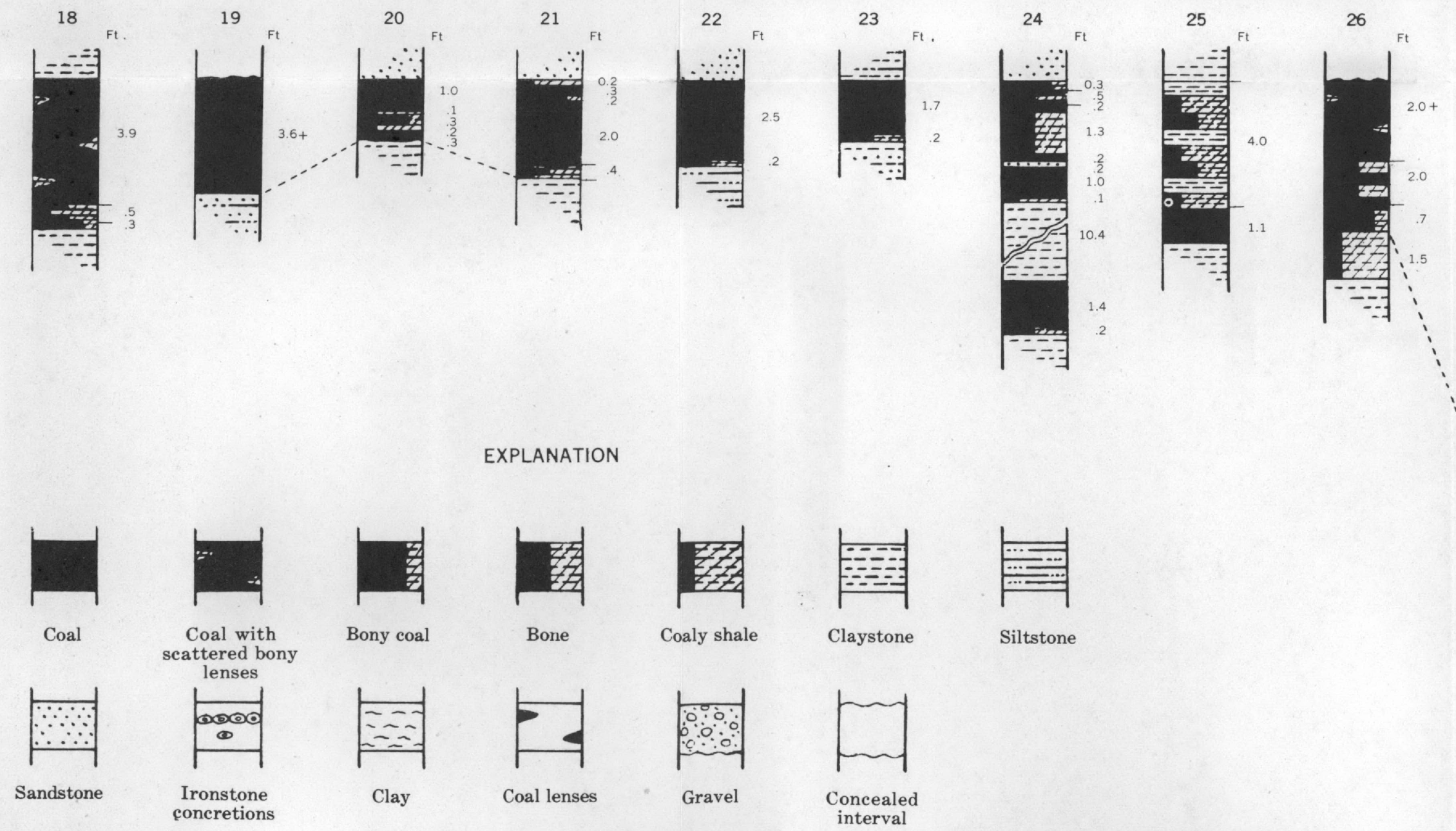

T. 1 S...R. 14 W.

T. 2 S..R. 14 W.
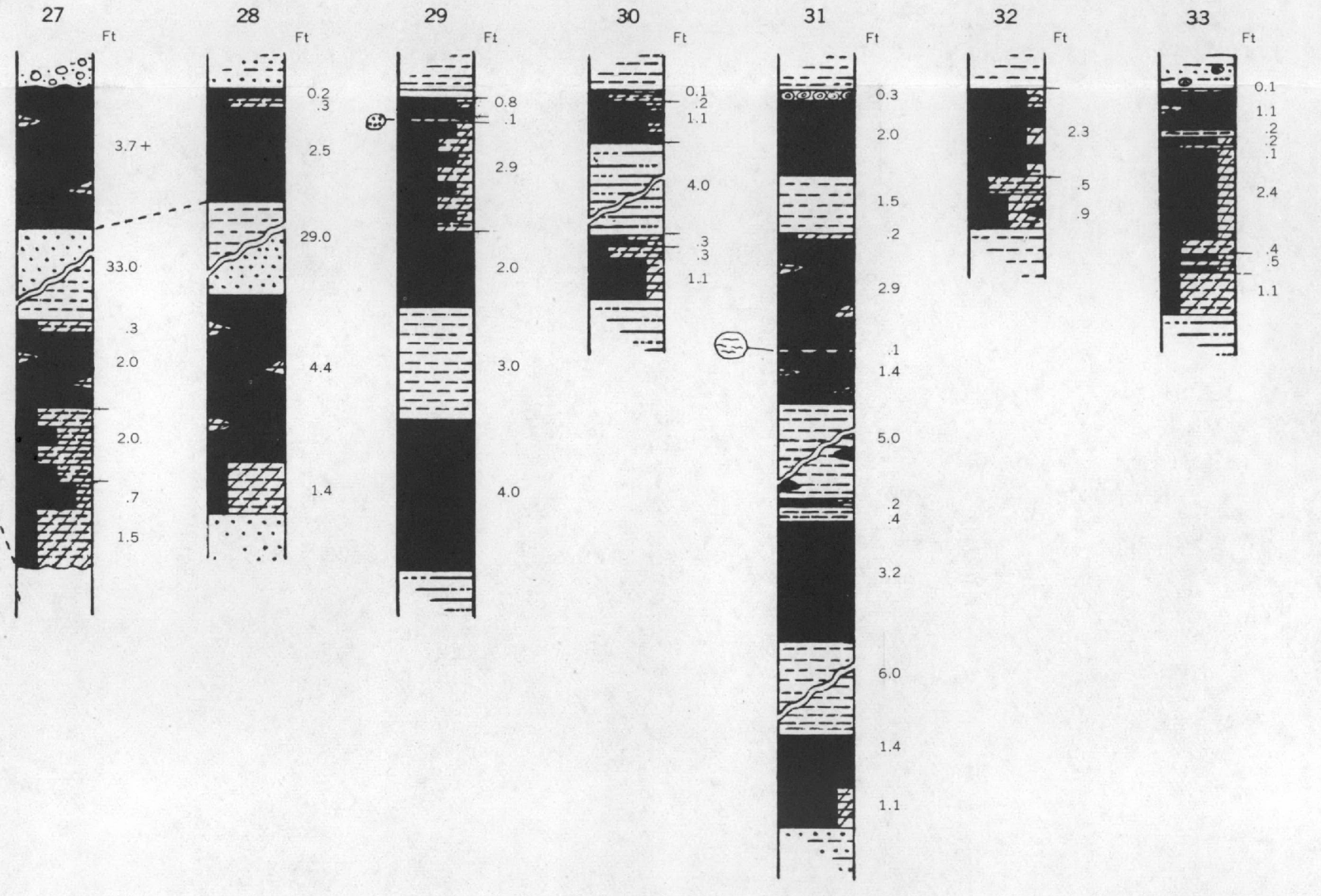

SECTIONS OF COAL BEDS AT LOCALITIES 1 TO 33 ON EAST SHORE OF COOK INLET BETWEEN CAPES KASILOF AND NINILCHIK. HOMER DISTRICT, ALASKA 



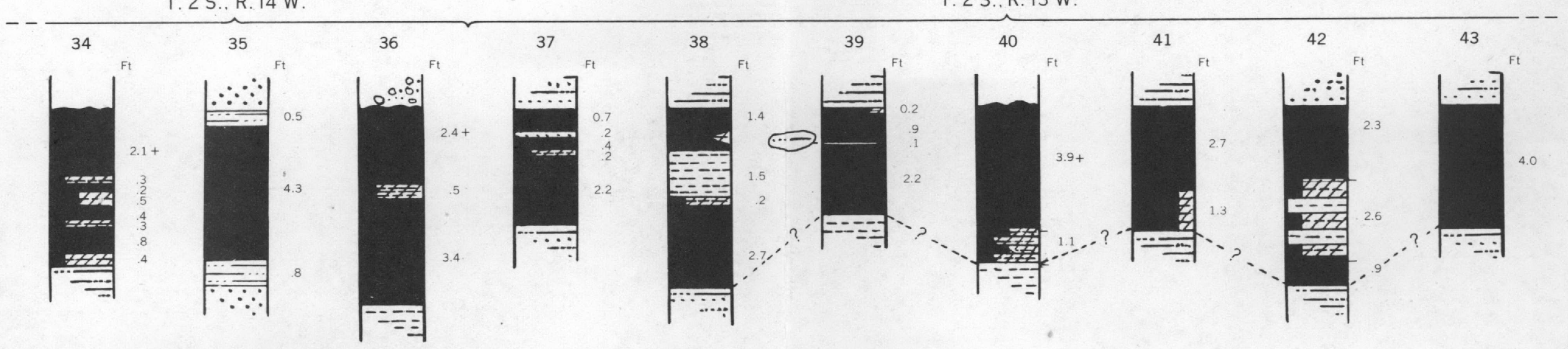

T. 2 S. R. 13 W.

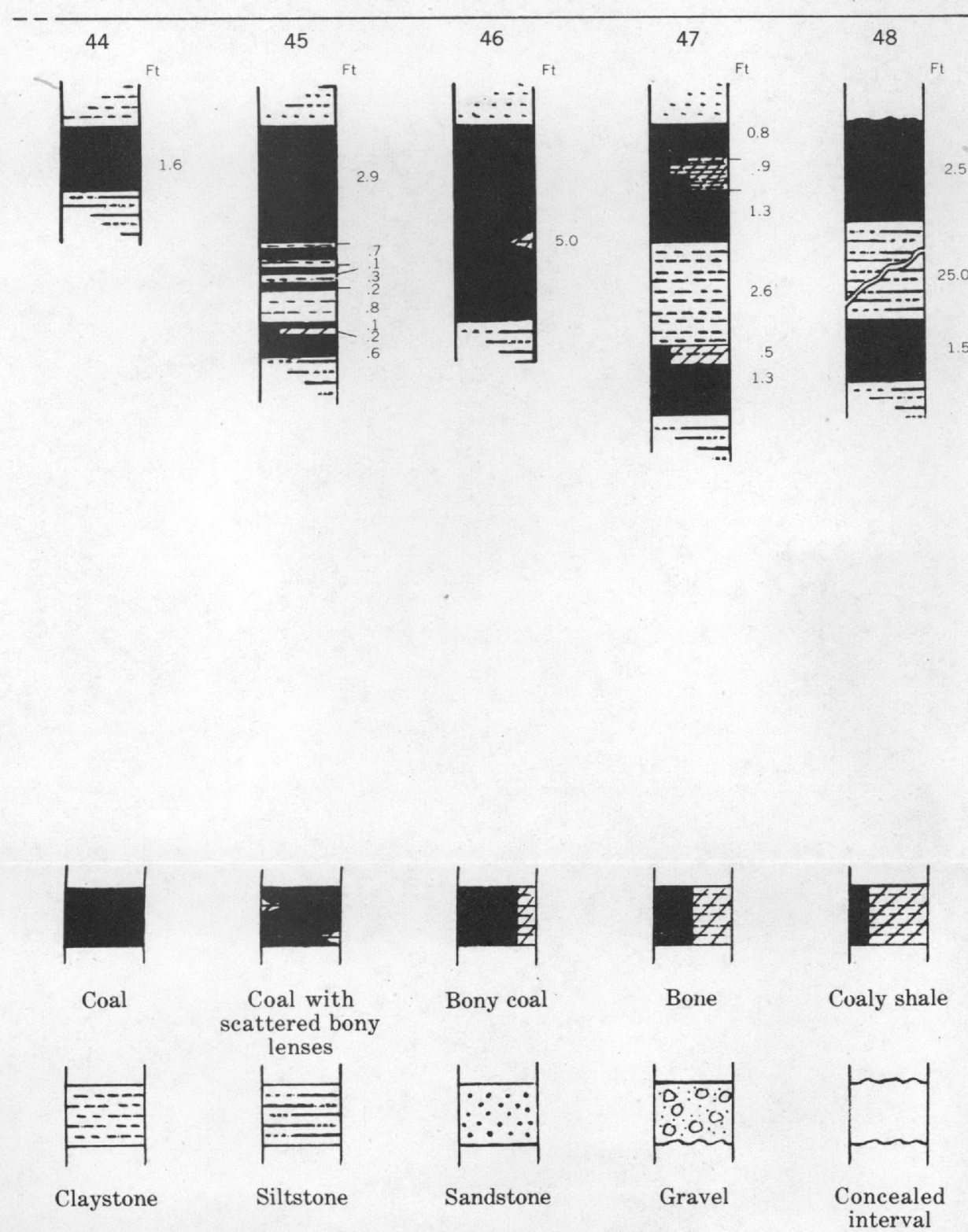

SECTIONS OF COAL BEDS AT LOCALITIES 34 TO 53 ON DEEP CREEK, HOMER DISTRICT, ALASKA 


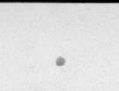



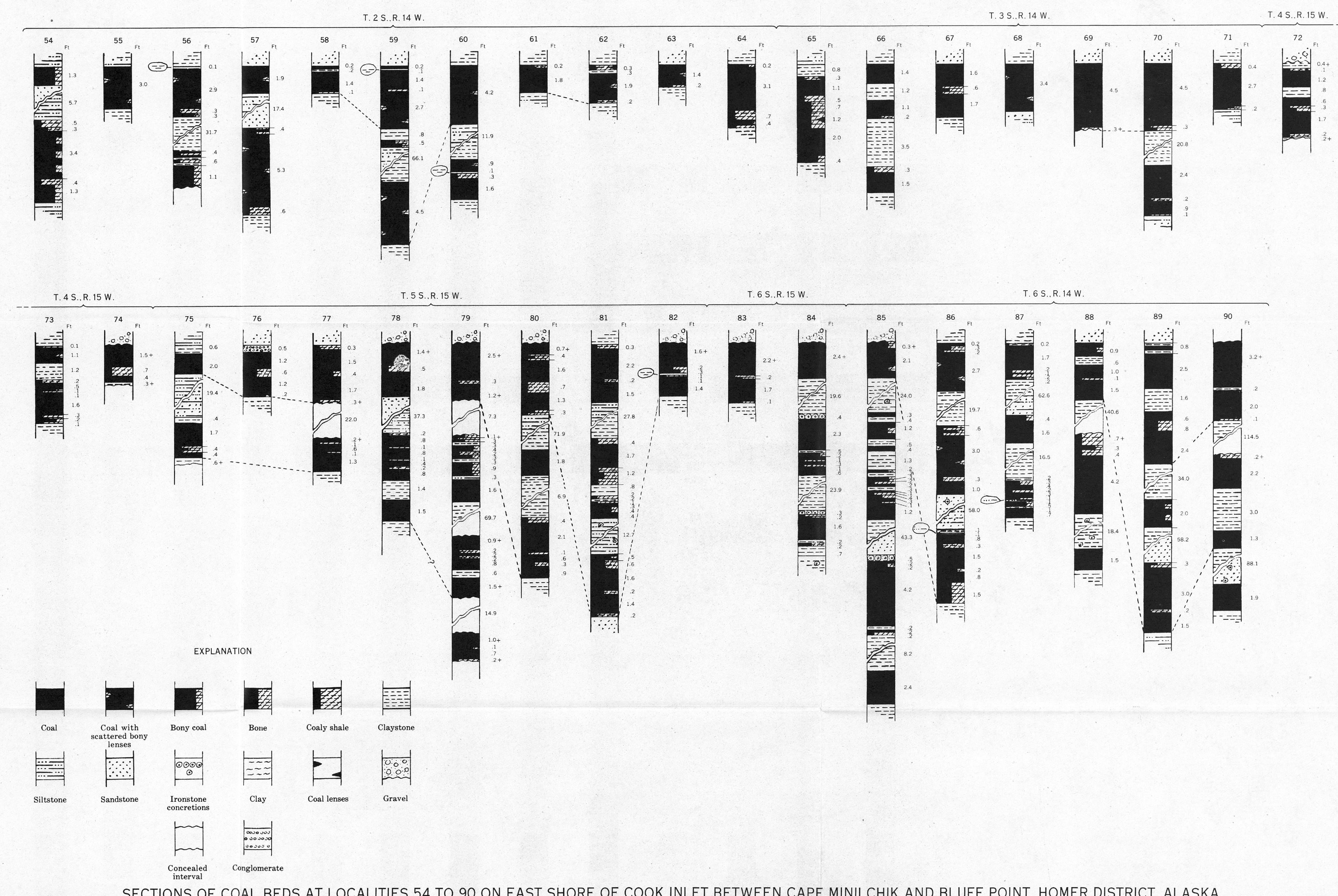

SECTIONS OF COAL BEDS AT LOCALITIES 54 TO 90 ON EAST SHORE OF COOK INLET BETWEEN CAPE MINILCHIK AND BLUFF POINT. HOMER DISTRICT, ALASKA 

Lofgren bed

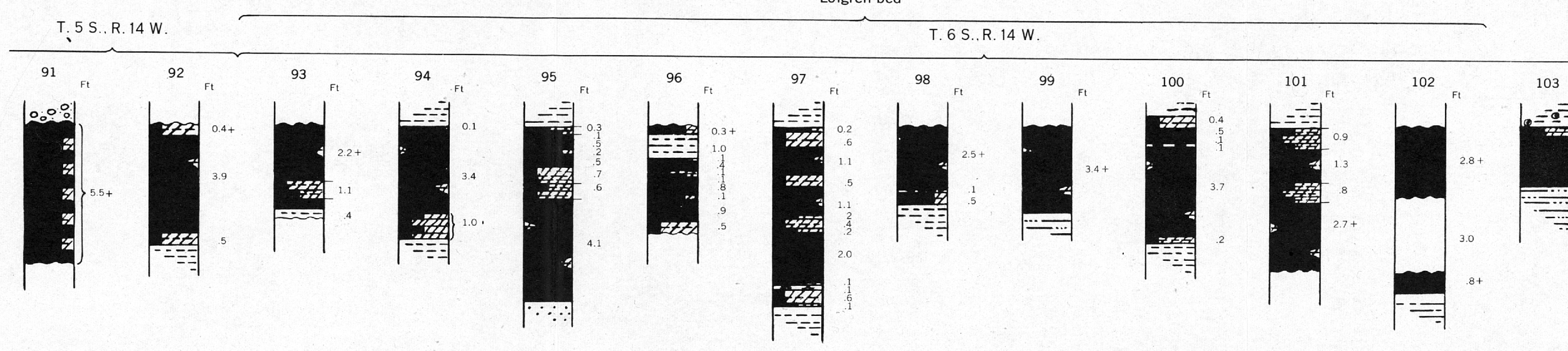
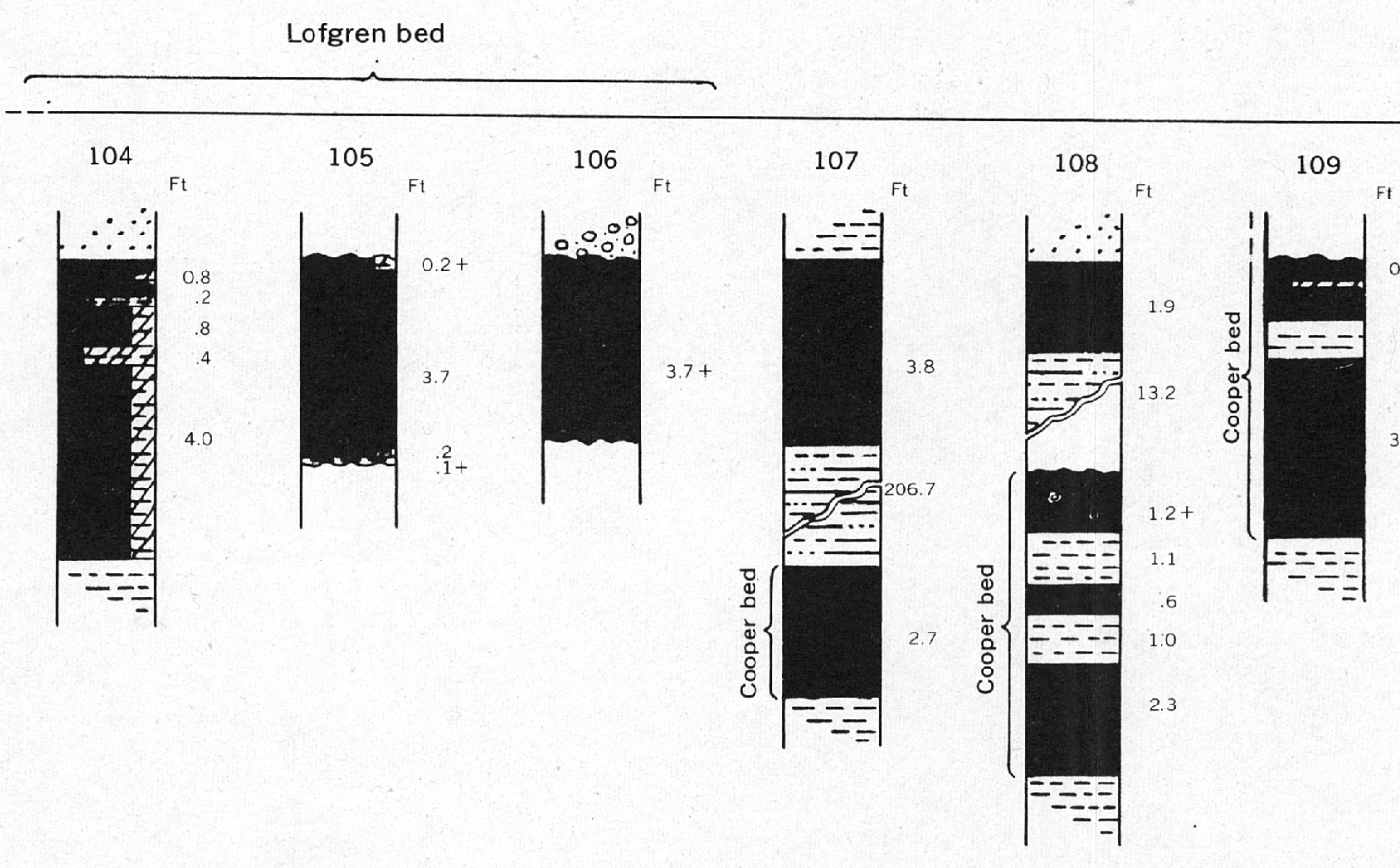

T. 6 S..R. 14 W.
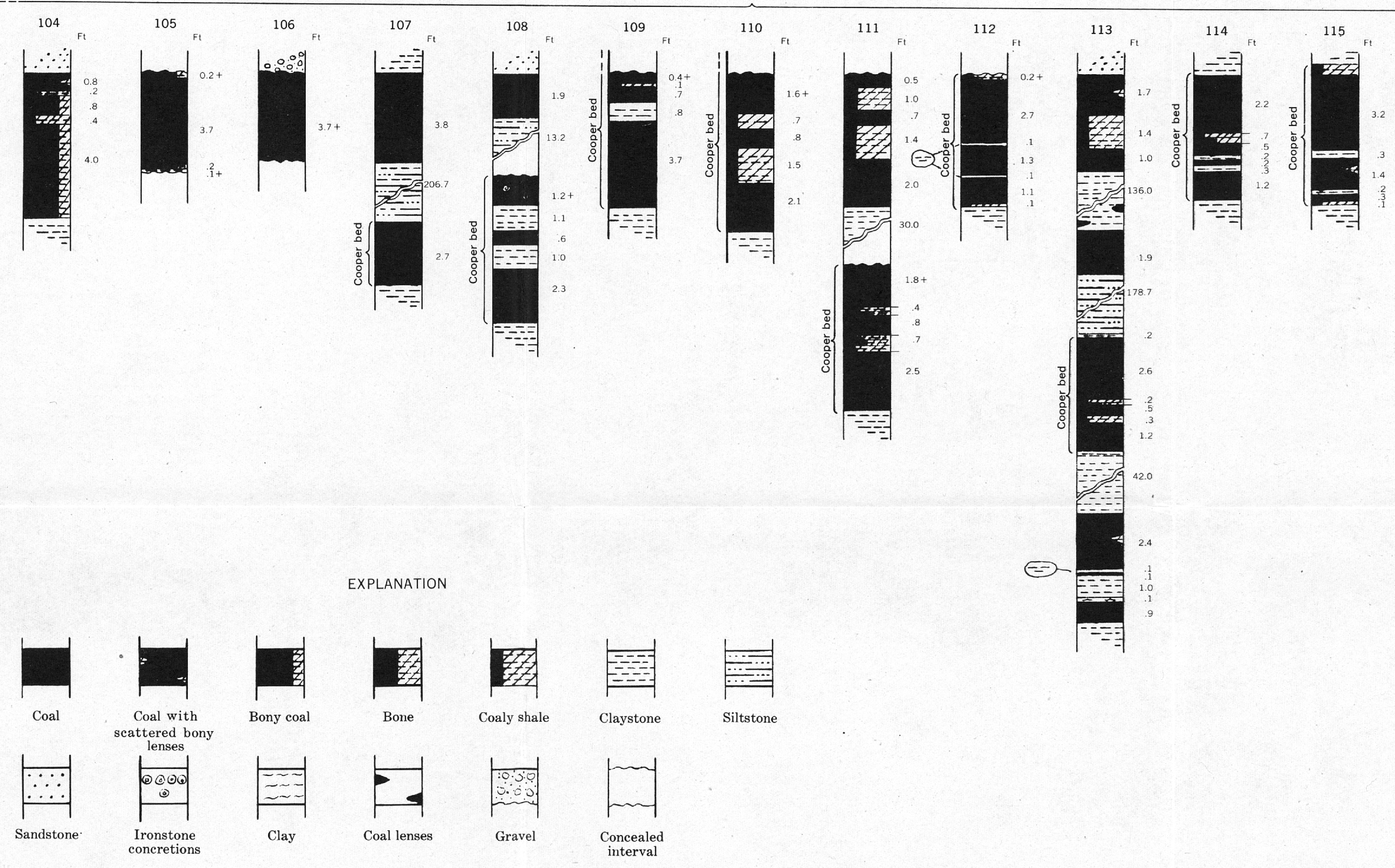



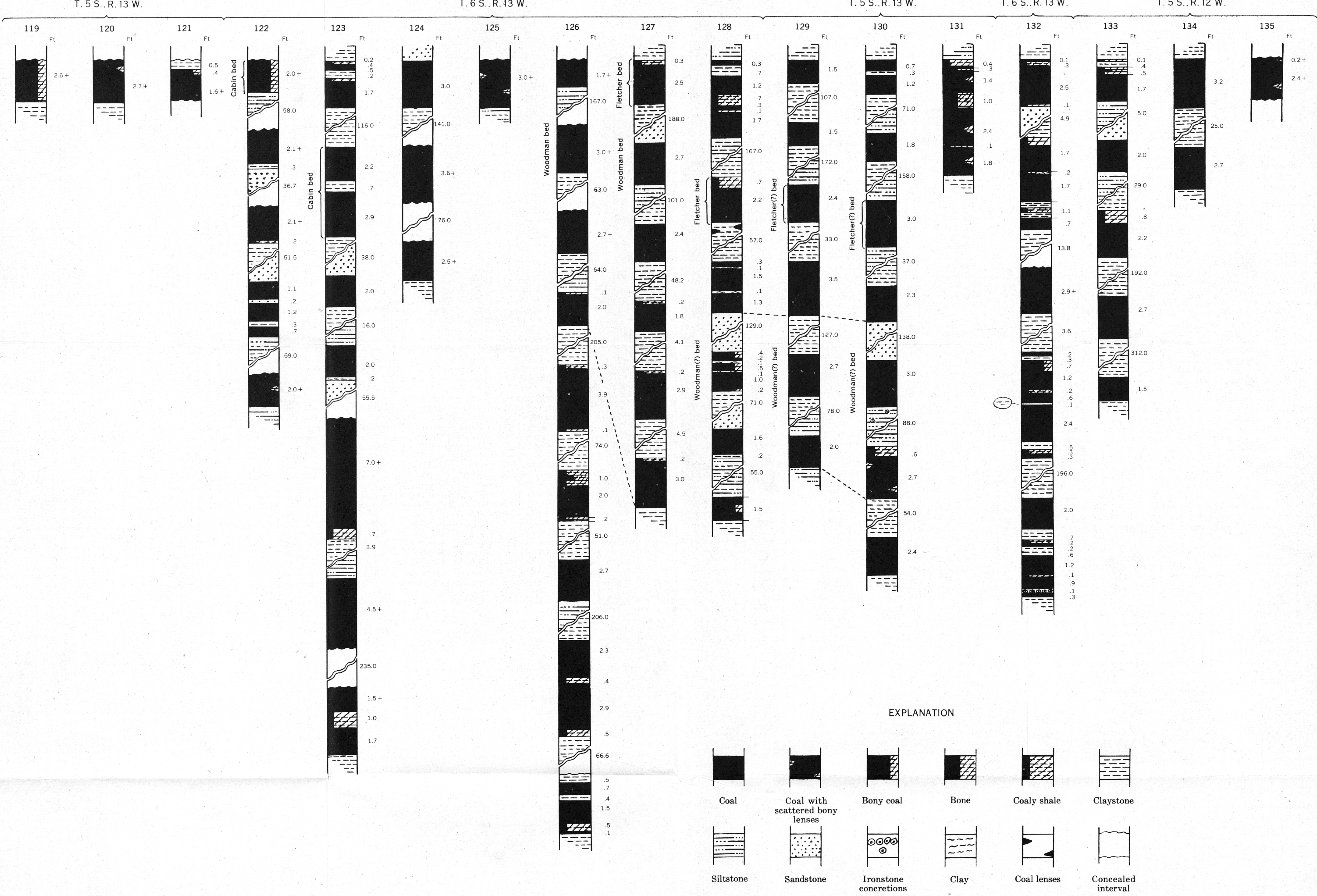





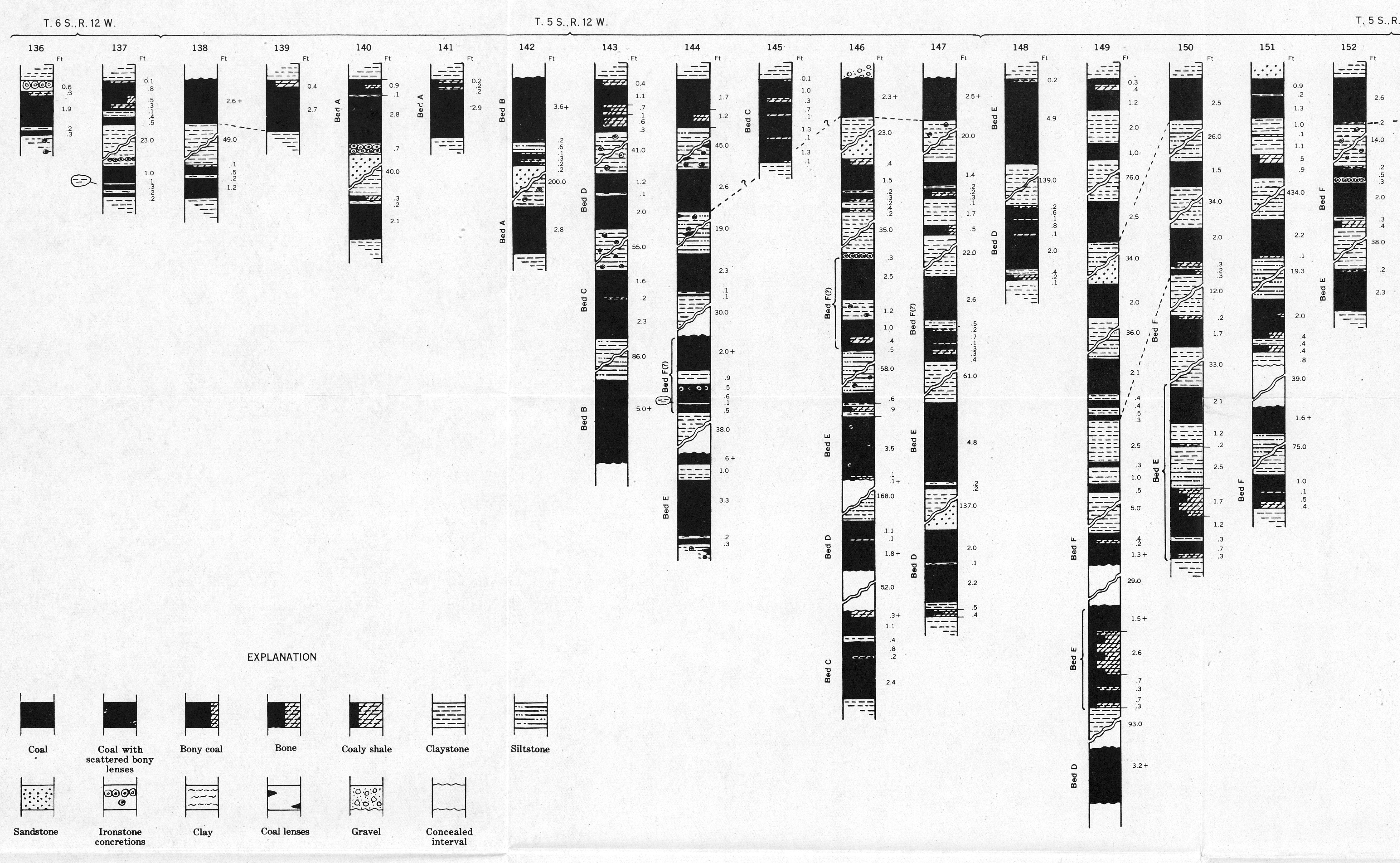

$111 \mathrm{~W}$.

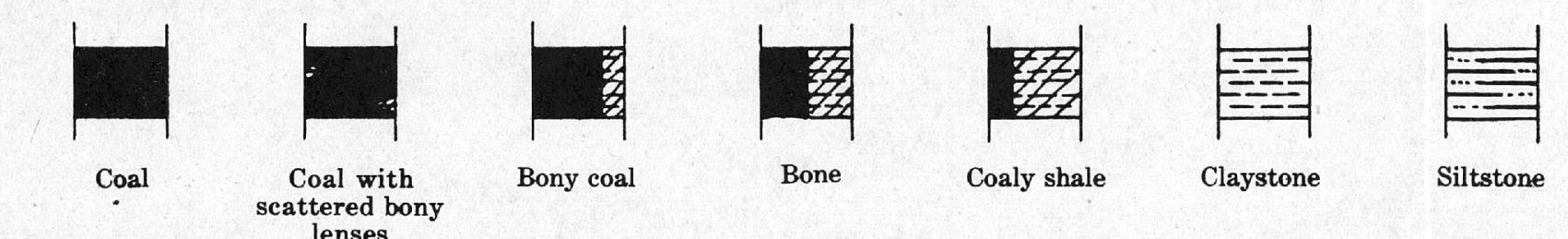

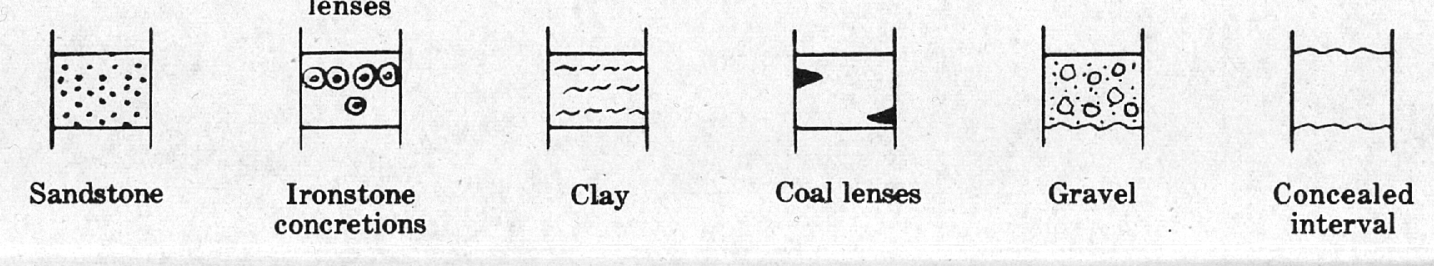
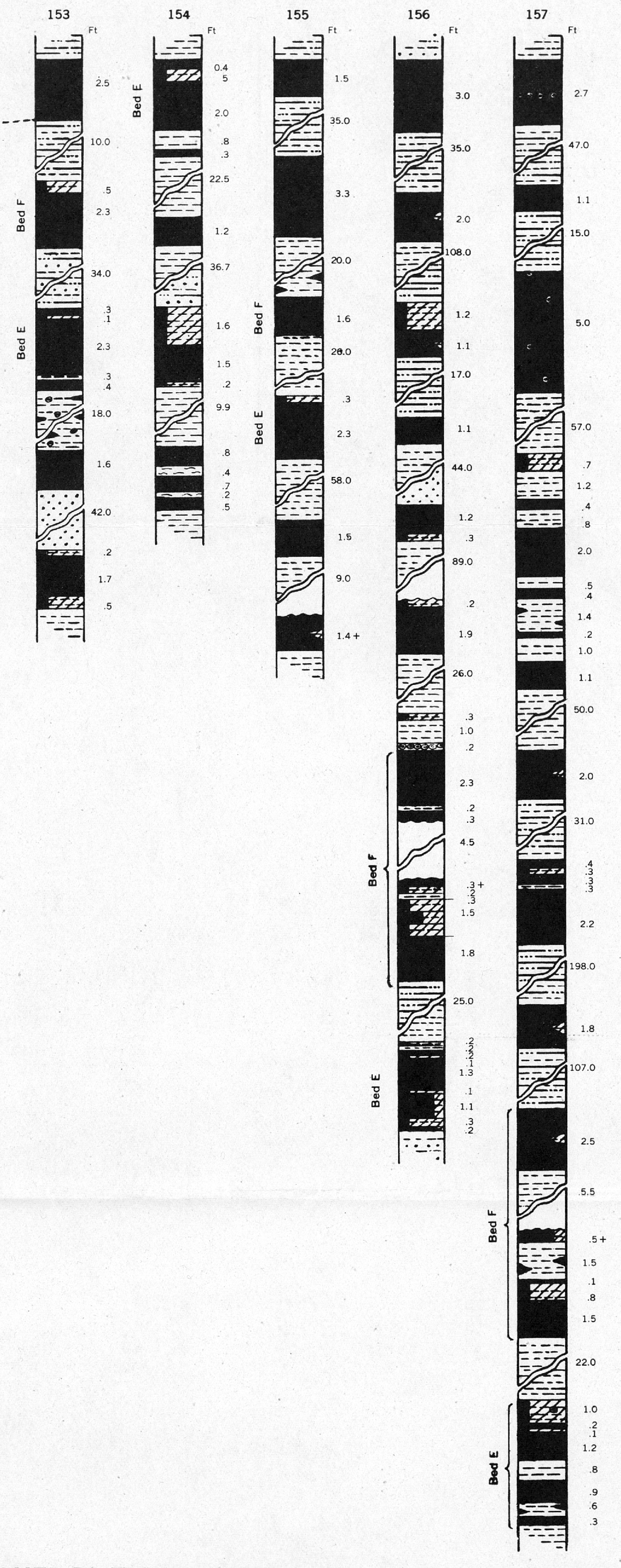

T. 4 S., R. 15 W.

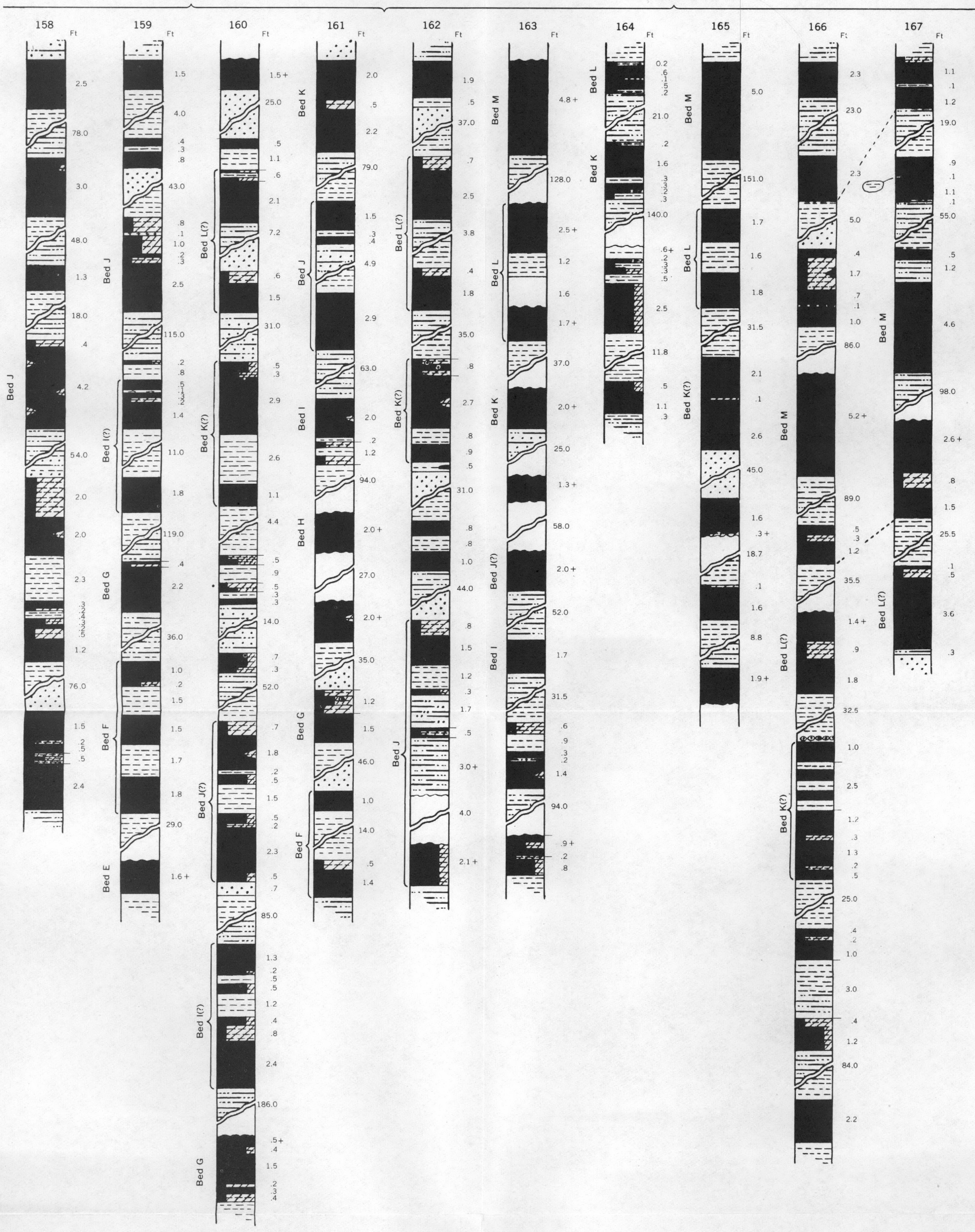

EXPLANATION

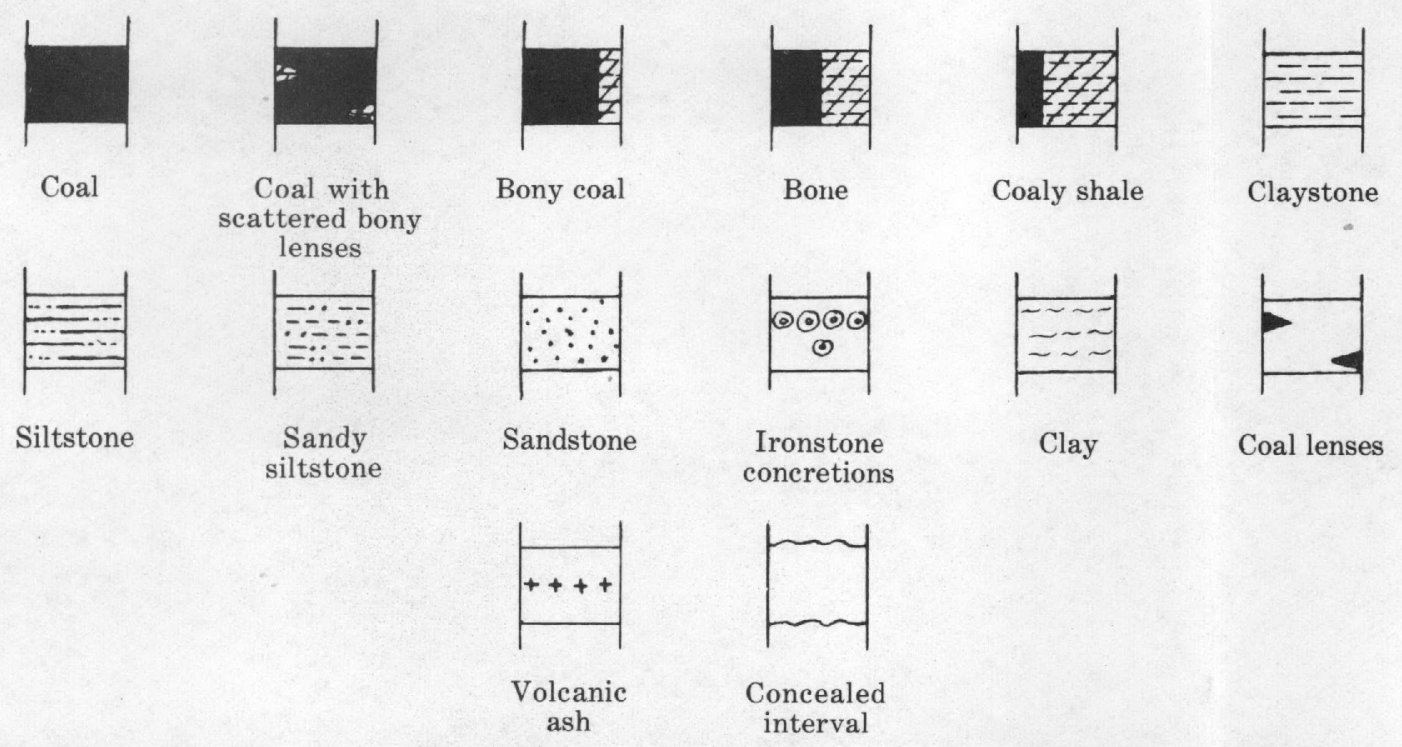





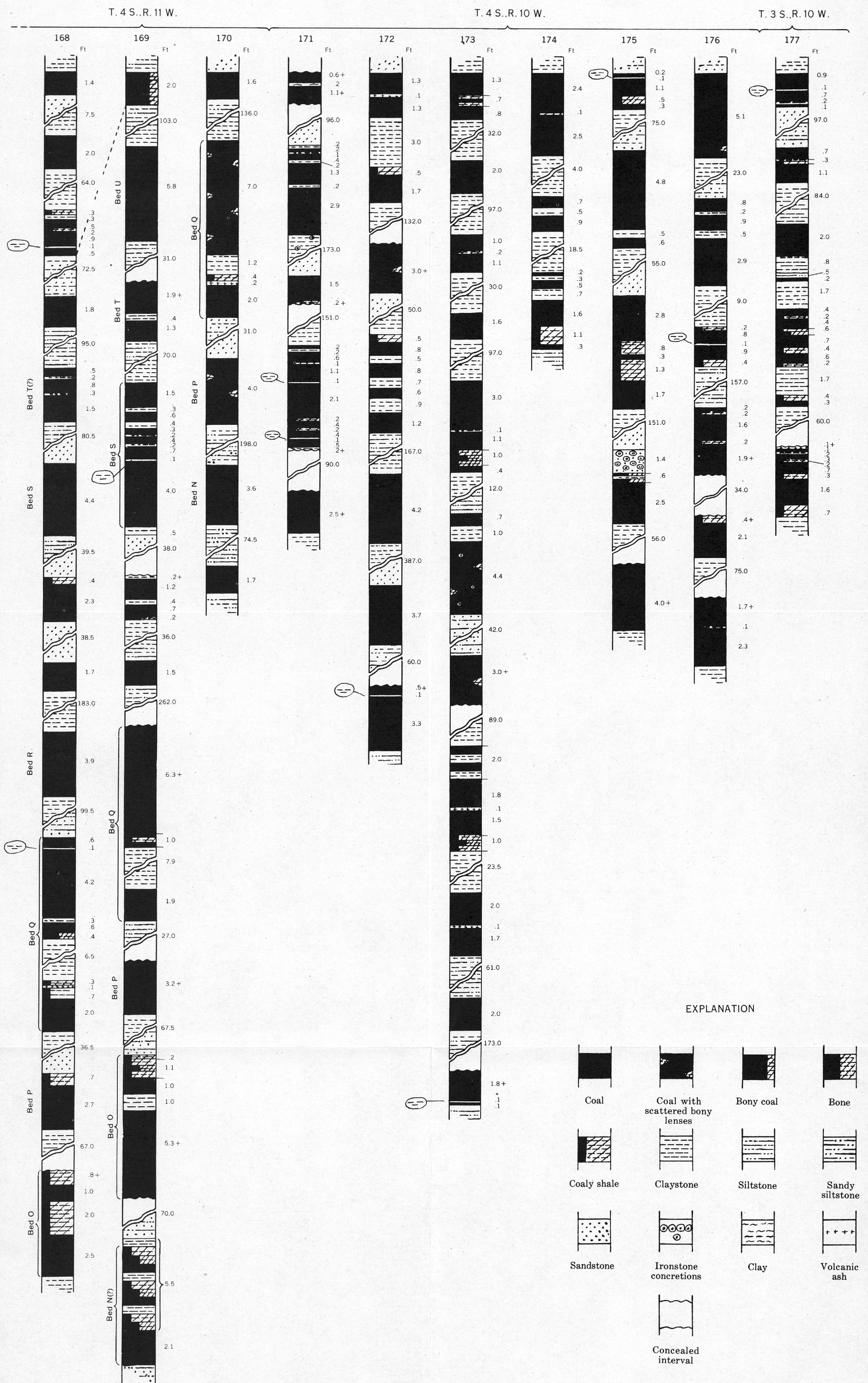



UNITED STATES DEPARTMENT OF THE INTERIOR

GEOLOGICAL SURVEY
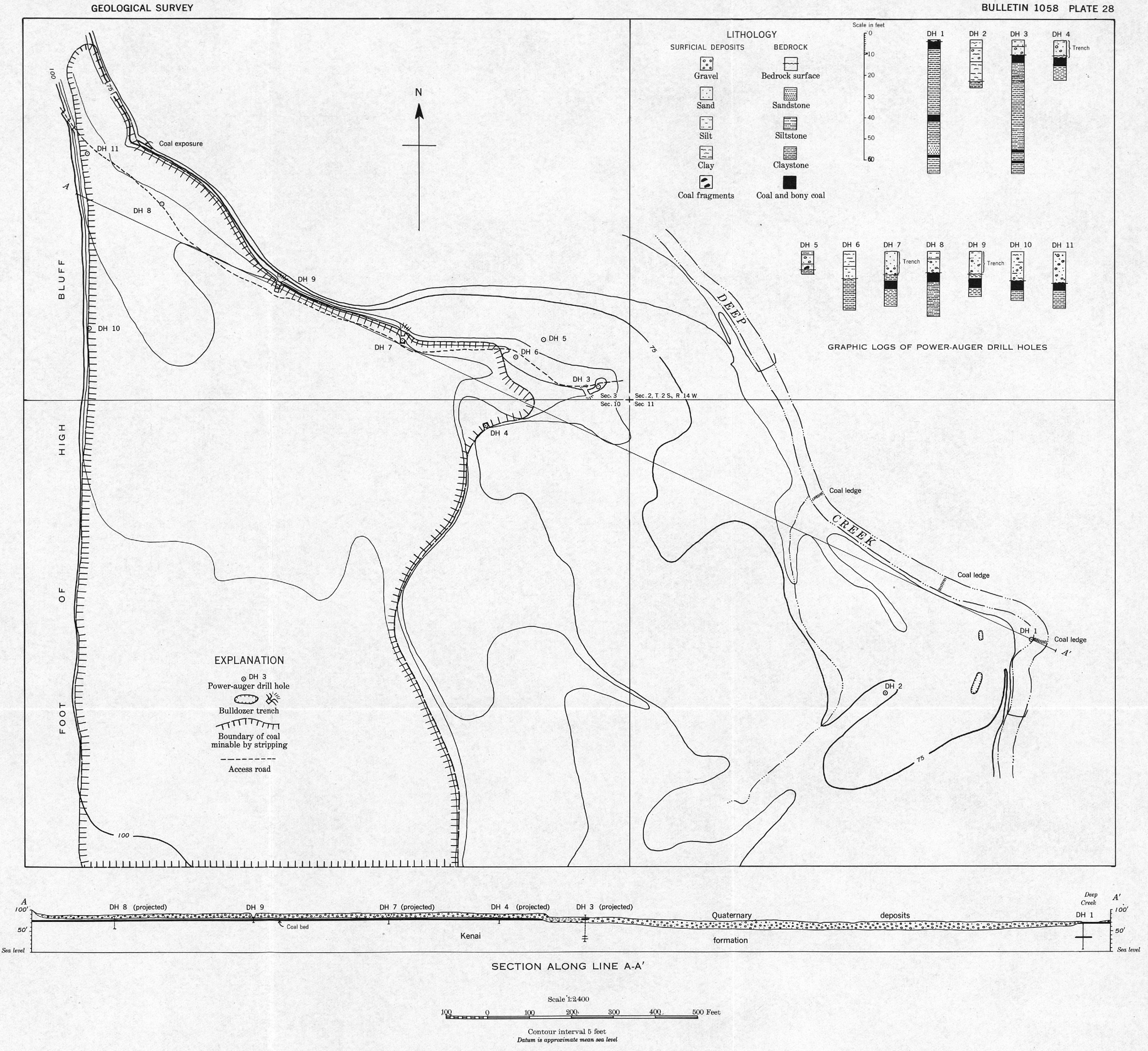

MAP AND SECTION OF LOWER DEEP CREEK AREA, HOMER DISTRICT, KENAI COAL FIELD, ALASKA WITH GRAPHIC LOGS OF POWER-AUGER DRILL HOLES 




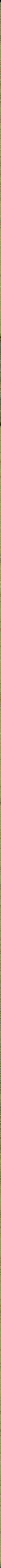

